\title{
The Invention of Common Law Play Right
}

\author{
Jessica Litman ${ }^{\dagger}$
}

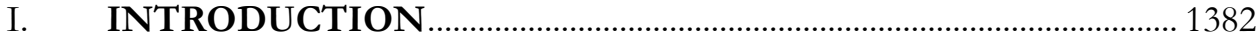

II. PLAY RIGHT IN ENGLAND ............................................................ 1387

A. English THEatre Before the StAtute of ANNE...................... 1389

B. ENGLISH THEATRE FROM THE STATUTE OF ANNE TO THE

1833 DRAMATIC LITERARY PROPERTY ACT .................................... 1396

C. STATUTORY PLAY RIGHT IN ENGLAND............................................... 1397

III. PLAY RIGHT IN AMERICA …………............................................. 1400

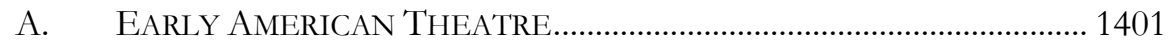

B. THE 1856 DRAMATIC COPYRIGHT ACT................................................. 1402

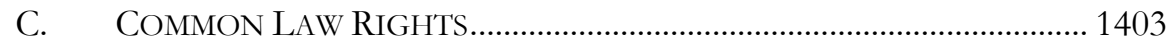

D. EATON DRONE'S NATURAL LAW PLAY RIGHT ................................. 1410

E. WhOSE PLAY Right? ............................................................................... 1416

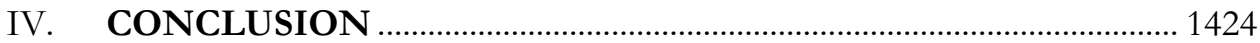

A dramatic composition is capable of two distinct public uses. It may be printed as a book and represented as a drama... The exclusive right of multiplying copies is called copyright. But this does not embrace the right of representation.... The sole liberty of publicly performing a dramatic composition might more properly be called dramatic right or acting right. . . I have adopted playright as being, in my judgment, the best name for the purpose. It is a convenient euphonious word, and its formation is analogous to that of copyright. As the latter word literally means the right to copy a work, or the right to the copy, so playright means the right to play a drama, or the right to the play.

$$
\text { —Eaton Sylvester Drone }{ }^{1}
$$

(C) 2010 Jessica Litman.

† John F. Nickoll Professor of Law, University of Michigan. I'm grateful to Pam Samuelson for thinking up this conference and inviting me to do this research, and to Jon Weinberg, Jody Kraus, Jane Ginsburg, Becky Eisenberg, and H. Tomás Gómez-Arostegui for their helpful comments on earlier drafts.

1. Eaton S. Drone, Treatise on the Law of Property in Intellectual Productions in Great Britain And the United States 553 (1879). Copyright in both Britain and the United States was initially limited to the right to print and sell copies. The 


\section{INTRODUCTION}

American copyright law nominally vests exclusive rights in "authors.", "Authors" in America, as often as not, are the employers of the individuals who actually create copyrightable works. ${ }^{3}$ Even when the law vests copyright in creators, the architecture of the system encourages them to assign their copyrights to intermediaries, who are motivated by potential profits to disseminate the works to the public. ${ }^{4}$ Employers and assignees stand in the authors' shoes and may control a work's exploitation to the exclusion of the individuals who created it. ${ }^{5}$ That's the essence of a copyright system that is fundamentally utilitarian in its design. With the narrow exceptions of painters and sculptors, American authors have no enforceable attribution or integrity rights. ${ }^{6}$ The originality standard for "meriting" copyright protection is low, and follow-on creators who add even a little creativity to authorized adaptations of copyrighted works are entitled to exclusive rights in their versions of those works. This is the American version of copyright law in a nutshell. ${ }^{7}$

In stark contrast to that model, consider the American playwright: the playwright keeps her copyright, rather than assigning it. In the United States, playwrights license public exploitation, and pay the intermediary exploiters with a share of the proceeds rather than ownership of the copyright. ${ }^{8}$ Playwrights assert strong, apparently enforceable rights to attribution and integrity. 'Playwrights, finally, insist that other creators who contribute

British Parliament and United States Congress later expanded copyright to encompass other rights. See infra notes 106-18, 134-38, 213-15, 261 and accompanying text.

2. See 17 U.S.C. $\int 201$ (a) (2006).

3. See U.S. Copyright Office, Works Made for Hire Under the 1976 Copyright Act, Circular 9 (revised Apr. 2010).

4. See Jessica Litman, Real Copyright Reform, 96 IOwA L. REV. (forthcoming 2010) (on file with author).

5. See, e.g., Okla. Natural Gas Co. v. Larue, Copyright L. Rep. (CCH) I 27,814 (10th Cir. 1998); Gross v. Seligman, 212 Fed. 930 (2d Cir. 1914).

6. See Roberta Kwall, The Soul of Creativity: Forging a Moral Rights LAW FOR THE UNITED STATES 23-35 (2009).

7. See Arthur R. Miller \& Michael H. David, Intellectual Property: Patents, Trademarks, and Copyright in a Nutshell 296-304, 383-404 (4th ed. 2007).

8. See, e.g., Donald C. Farber, Producing Theatre 1-33 (3d rev. ed. 2006).

9. See, e.g., Donald C. Farber, From Option to Opening: A Guide to Producing Plays Off Broadway 21 (5th ed. rev. 2005); Samuel G. Freedman, Who's to Say Whether a Playwright is Wronged, N.Y. TIMES, Dec. 23, 1984, at E6; United Press Int'l, Albee Seeking to Close All-Male "Woolf," N.Y. Times, Aug. 3, 1984, at C5; Dramatists Guild of Am., Dramatists Bill of Rights, http://www.dramatistsguild.com/billofrights/ (last visited Aug. 3, 2010); Dramatists Play Service, Frequently Asked Questions (FAQs), 
significant creative expression to licensed productions of their scripts have added no authorship and should receive no copyright protection for their additions. ${ }^{10}$

What accounts for the differences? There's no obvious language in the copyright statute suggesting that dramatists or their plays be treated as unique legal beasts. The current copyright statute includes several relatively minor provisions that single dramatic works out for more favorable treatment in particular narrow contexts. ${ }^{11}$ In general, the category of dramatic works (which Congress doesn't even bother to define) is treated the same way as other subject matter categories. Federal copyright cases involving dramatic works are surprisingly scant.

For most of the 18th, 19th, and 20th centuries, the contours of federal statutory copyright and the formal prerequisites for perfecting it fit dramatic works poorly. Until 1978, American copyright law focused chiefly on works that had been published-for most works, publication was the quid pro quo

http://www.dramatists.com/faqsmanager/applications/faqsmanager/ (last visited Aug. 3, 2010).

10. See, e.g., John Weidman, Protecting the American Playwright: The Seventh Annual Media and Society Lecture, 72 BROOK. L. REV. 639, 641-42 (2007); Ralph Sevush, The Urinetown Papers: The U.S. Copyright Office Debunks the Notion of a "Directors Copyright," THE DramatiST, Mar.-Apr. 2009, at 30; Dramatists Guild of Am., Dramatists' Copyright \& Intellectual Property Rights, Apr. 2000, http://www.dramatistsguild.com/about_statements_copyright.aspx (last visited Feb. 2, 2010); see also Thomson v. Larsen, 147 F.3d 195 (2d Cir. 1998) (holding dramaturg was not a joint author of musical because composer/dramatist did not intend to share authorship credit); Erickson v. Trinity Theatre, 13 F.3d 1061 (7th Cir. 1994) (holding actors were not joint authors of three plays because their contributions were not independently copyrightable); Childress v. Taylor, 945 F.2d 500 (2d Cir. 1991) (holding actress not a joint author of one-woman play because dramatist did not intend to share authorship credit). But see, e.g., Carrie Ryan Gallia, Note, To Fix or Not to Fix, Copyright's Fixation Requirement and the Rights of Theatrical Collaborators, 92 MINN. L. REV. 231, 264 (2007) ("By transforming a stack of pages into a live performance, a director demonstrates sufficient originality."); Margit Livingston, Inspiration or Imitation? Copyright Protection for Stage Directions, 50 B.C. L. REV. 427, 486 (2009) ("[A] straightforward application of traditional copyright law would dictate that stage directions are subject to copyright protection.”).

11. Section 110 expressly limits some of its exemptions for noncommercial performances or displays to "non-dramatic literary or musical works," excluding dramatic works, choreographic works, pictorial graphic and sculptural works, motion pictures and other audiovisual works and architectural works. Section 118 limits the scope of the statutory noncommercial broadcasting license to "published nondramatic musical works and published pictorial, graphic and sculptural works." Section 121 limits the scope of the exemption for reproduction and distribution of copies or phonorecords in formats accessible for people with disabilities to "previously published, non-dramatic literary work." Those distinctions, though, don't begin to explain the more fundamental differences in copyright ownership and control described in the text accompanying notes 8-10. 
for statutory copyright protection. ${ }^{12}$ The vast majority of plays, even those that were exploited commercially, were never published as U.S. copyright law defined it. ${ }^{13}$ Playwrights in America until 1909 faced a choice of arranging to publish their scripts to secure federal statutory protection or relying on whatever copyright protection state courts might afford unpublished works. ${ }^{14}$ That dilemma persuaded Congress in 1909 to permit copyright registration for unpublished plays. ${ }^{15}$ While thousands of unpublished play scripts were registered, ${ }^{16}$ very few of them became involved in federal litigation. ${ }^{17}$ Important questions about how the copyright statute applied to works registered as unpublished, such as the duration of rights for unpublished works, ${ }^{18}$ remained unresolved for years. ${ }^{19}$

Instead of relying on federal statutory copyright, lawyers for dramatists claimed that their clients' work was better protected under state "common law copyright." 20 The 1909 Copyright Act expressly preserved "the right of the author or proprietor of an unpublished work, at common law or in

12. L. Ray Patterson, Free Speech, Copyright and Fair Use, 40 VAND. L. REV. 1, 2-12, 3334 (1987); Pamela Samuelson, CONTU Revisited: The Case Against Copyright Protection for Computer Programs in Machine-Readable Form, 1984 DUKE L.J. 663, 705-06.

13. See, e.g., BARretT H. Clark, 1 America's Lost Plays v-vi (1940).

14. See Revision of the Copyright Laws: Hearings on Pending Bills to Amend and Consolidate the Acts Respecting Copyright Before the House and Senate Comm. on Patents, 60th Cong. 21-41 (1908) (testimony of witnesses representing the American Dramatists Club and the National Association of Theatrical Managers); 1 Library of CONG. COPYRight OfFICE, DramatiC COMPOSITIONS COPYRIGHTED IN THE UNITED STATES 1870 TO 1916, at 1 (1918).

15. Copyright Act of Mar. 4, 1909 \& 11, 35 Stat. 1075, 1078 (later § 12).

16. See Library of Cong., Fifty-Fourth Annual Report of the Register of COPYRIGHTS FOR THE FISCAL YEAR ENDING JUNE 30, 1951, at 2 (1952); Library OF CONG., REPORT OF THE REGISTER OF COPYRIGHTS FOR THE FISCAL YEAR 1924-25, at 19697 (1925); LIBRARY OF CONG., REPORT OF THE REgISTER OF COPYRIGHTS FOR THE FISCAL YEAR 1918-19, at 138-39 (1919).

17. See, e.g., Rosen v. Loew's, Inc., 162 F.2d 785 (2d Cir. 1947) (holding the authors of "The Mortal Storm" did not copy "The Mad Dog of Europe"); Marx v. United States, 96 F.2d 204 (9th Cir. 1938) (affirming criminal conviction for infringement of radio script); Davis v. E.I DuPont De Nemours \& Co., 240 F. Supp. 612 (S.D.N.Y. 1965) (holding play based on novel "Ethan Frome" to be infringed by TV movie).

18. See Marx v. United States, 96 F.2d 204 (9th Cir. 1938) (holding that twenty-eight year duration for published works should also apply to registered unpublished work, but the date of deposit should be deemed the date of publication).

19. William S. Strauss, Protection of Unpublished Works (1957), in 1 COPYRIGHT SOCIETY OF THE USA, STUDIES ON COPYRIGHT 190, 196 (1963).

20. See, e.g., House Comm. on the Judiciary, 88Th Cong., Copyright LaW REVISION PART 2: DisCussion AND COMMENTS ON THE REPORT OF THE REgISTER OF Copyrights on the General ReVIsion of the U.S. Copyright LaW 312 (Comm. Print 1963) (letter from Irwin Karp, May 29, 1961); Philip Wittenberg, The Protection And Marketing of Literary Property 11-14 (1937); Benjamin Kaplan, Publication in Copyright Law: The Question of Phonograph Records, 103 U. PA. L. REV. 469, 473-79 (1955). 
equity, to prevent the copying, publication, or use of such unpublished work without his consent...."21 A 1957 Copyright Office study of state common law copyright described it as giving authors "absolute rights in an unpublished work" 22 that were "not subject to the limitations imposed by the statute upon copyright." 23 The rights "continue perpetually as long as the work remains unpublished, unless ... the owner voluntarily chooses to secure statutory copyright by registration in the Copyright Office." 24 The scope of the playwrights' common law right was perceived to be broader than the common law copyright at issue in Wheaton v. Peters, ${ }^{25}$ encompassing what we would today identify as adaptation and public performance rights as well as reproduction and distribution rights. In 1879, treatise author Eaton Drone dubbed the common law public performance right in unpublished dramatic works "playright," 26 and, at least for a time, the usage enjoyed favor. $^{27}$

This Article explores playwrights' common law "play right." Since this conference celebrates the 300th birthday of the Statute of Anne, I begin in England in the 17 th Century. I find no trace of a common law playwright's performance right in either the law or the customary practices surrounding 17th and 18th century English theatre. I argue that the nature and degree of royal supervision of theatre companies and performance during the period presented no occasion (and, indeed, left no opportunity) for such a right to arise. I discuss the impetus for Parliament's enactment of a performance

21. Copyright Act of Mar. 4, 1909 \2, 35 Stat. 1075, 1075.

22. Strauss, supra note 19, at 191 (citing Drone, supra note 1, at 8).

23. Id. at 194

24. Id. at 191; see George A. Warp, The Position of the Dramatist in Copyright Law, 22 B.U. L. REV. 528, 529-30 (1942).

25. Wheaton v. Peters, 33 U.S. (8 Pet.) 591 (1834); see L. RAY PATterson, COPYRIGHT In Historical Perspective (1968). See generally Craig Joyce, The Story of Wheaton v. Peters: A Curious Chapter in the History of Judicature, 42 HOUs. L. REV. 325 (2006).

26. Drone, supra note 1, at 553. Drone used the single word "playright" because of its parallel to "copyright" and the courts following Drone did so as well. In this essay, I use "play right" unless I am quoting to minimize confusion.

27. See, e.g., Fitch v. Young, 230 F. 743, 744 (S.D.N.Y. 1916) (Hand, J.) ("I think that play right and copyright are quite distinct under the statute, in spite of the fact that printed publication will forfeit both, and that one statutory copyright will protect both.”); R.R. BOWKER, COPYRIGHT: ITS History AND ITS LAW 162 (1912) ("[T] he new American code provides not only for copyright, but for playright or right of performance."); WILLIAM Morris Colles \& Harold Hardy, Playright and Copyright in All Countries 1 (1906) ("The playright is more valuable, as a rule, than the copyright in a play. ..."); Charles Collins, Playright and the Common Law, 15 CALIF. L. REV. 381, 381 (1925) ("Playright is a word coined by Mr. Drone... . It has been adopted by the Supreme Court of the United States and is accordingly preferred...." (citation omitted)); Warp, supra note 24, at 546 ("[T] he term 'playright' refers to the exclusive right to present dramatic works.”). 
right statute in 1833, and its decision, nine years later, to adopt a law that scuttled any nascent tendencies supporting the development of a common law performance right by equating public performance with publication for the purposes of copyright.

I then cross the Atlantic to the United States, and note that the colonies and the young nation imported their actors, managers, plays, and customary theatrical practices from England. I again find no trace of a common law play right before 1856. That year was the year that Congress followed the British example and enacted a statutory public performance right for the authors and proprietors of dramatic compositions. ${ }^{28}$ The first common law performance right cases show up shortly thereafter, as courts sought to respond to formal defects in the copyrights of claimants seeking to enforce their rights under the new statute. ${ }^{29}$

In 1879, Eaton Drone relied on an expansive natural rights theory about the true nature of copyright to draw from these cases a generous depiction of play right as a perpetual entitlement without exceptions. ${ }^{30}$ Courts adopted Drone's version of common law play right and followed it for the next thirty years. ${ }^{31}$ The availability of a strong natural right claim, however, made little difference to actual playwrights, who were deemed to have assigned their rights to the producers of their plays.

The strong copyright-like rights that playwrights enjoy today are chiefly contractual, secured for them in 1926 by the collective action of members of the Dramatists' Guild, who claimed to be a labor union and thus entitled to an antitrust exemption. ${ }^{32}$ Courts would later rule that the exemption was not available to the Guild, ${ }^{33}$ but its members and the theatre producers it contracts with continued to behave, most of the time, as if they were bound by Guild contracts. Meanwhile, the broad Drone view of natural rights copyright fell out of fashion, to be replaced, first, by a utilitarian publicinterest account ${ }^{34}$ and later by a utilitarian broad property rights account. ${ }^{35}$

28. Act of Aug. 18, 1856, 11 Stat. 138.

29. E.g., Keene v. Wheatley, 14 F. Cas. 180 (C.C.E.D. Pa. 1861).

30. DRONE, supra note 1, at 553-600; see infra notes 173-89 and accompanying text.

31. See, e.g., Frohman v. Ferris, 87 N.E. 327 (Ill. 1909), aff'd, 223 U.S. 424 (1912); Tomkins v. Halleck, 133 Mass. 32 (1882).

32. See An Arbiter to Keep Peace in Theatre, N.Y. Times, Mar. 23, 1926, at 24; infra notes 238-45 and accompanying text.

33. Ring v. Spina, 148 F.2d 647 (2d Cir. 1945); see text accompanying infra notes 25260 .

34. See, e.g., Wendy J. Gordon, Fair Use as Market Failure: A Structural and Economic Analysis of the Betamax Case and its Predecessors, 82 Colum. L. REV. 1600, 1602 (1982) ("The ultimate goal is not author remuneration, however, but the advancement and dissemination 
The evolution of attitudes about the nature of copyright made no appreciable change in playwrights' lives or livelihoods.

\section{PLAY RIGHT IN ENGLAND}

Since our conference is celebrating the 300th birthday of the Statute of Anne, we should begin by examining the common law literary property rights that playwrights enjoyed in the century preceding the enactment of the Statute of Anne. If playwrights' "play right" derives from common law sources, one might expect to be able to find the sources of a common law play right in the case law of the 17 th and early 18th century. The examination need not keep us for long, because it seems evident from all sources that playwrights enjoyed no literary property rights in their scripts. Playwrights' common law rights are apparently of more recent origin.

First, some common ground: the notion that common law copyright predated statutory copyright in England was first advanced by members of the stationers' guild, after the enactment of the Statute of Anne, to press claims for perpetual printing monopolies. ${ }^{36}$ The evidence they offered to support their theory of perpetual common law copyright was longstanding "stationers' copyright," a naked horizontal restraint of trade under which members of the Worshipful Company of Stationers agreed not to reprint any text first claimed by another member. ${ }^{37}$ Stationers treated members' assertions of exclusive rights to a text as perpetual, permitting them to be sold to or inherited by other members of the Guild. ${ }^{38}$ Since stationers commonly (although not invariably) paid the owner of a manuscript something in return for the privilege of printing it, they claimed that they

of culture and knowledge."). See generally Lloyd L. Weinreb, Copyright for Functional Expression, 111 HARV. L. REV. 1149, 1215-16 (1998) (remarking trend).

35. See, e.g., Robert Merges, Contracting Into Liability Rules: Intellectual Property Rights and Collective Rights Organizations, 84 CALIF. L. REV. 1293 (1996). See generally Neil Netanel, Why Has Copyright Expanded? Analysis and Critique, in 6 NeW DireCTIONS IN COPYRIGHT LAW 3 (Fiona MacMillan ed., 2007) (criticizing trend); Diane Leenheer Zimmerman, Copyright As Incentives: Did We Just Imagine That?, 12 THEORETICAL INQUIRIES IN LAW (forthcoming 2010) (arguing that research in psychology and behavioral economics cast doubt on incentive theory of copyright).

36. E.g., Howard Abrams, The Historic Foundation of American Copyright Law: Exploding the Myth of Common Law Copyright, 29 WAYNE L. REV. 1119, 1129-47 (1983). See generally RONAN DEAZLEY, ON THE ORIGINS OF THE RIGHT TO COPY 191-210 (2004).

37. See John Feather, Publishing, Piracy and Politics: An Historical Study of Copyright IN BRITAIN 15-36 (1994); Edward S. Rogers, Some Historical Matter Concerning Literary Property, 7 MiCH. L. REV. 100, 105-09 (2008).

38. See Don-John Dugas, Marketing the Bard: Shakespeare in Performance AND PRINT 1660-1740, 93-94 (2006); MARK Rose, Authors AND Owners: The INVENTION OF COPYRIGHT 12 (1993). 
must by their payment have purchased a perpetual common law literary property right. ${ }^{39}$ Stationers argued unsuccessfully in court that this perpetual common law right survived the enactment of the Statute of Anne. ${ }^{40}$

Copyright historians have examined the evidence supporting the existence of a common law literary property right in 17th century England and persuasively debunked it. ${ }^{41}$ To the extent that common law literary property rights may be said to have existed in some place and at some time, they did not precede the enactment of the Statute of Anne. For most purposes, the inquiry is of only academic interest, because the British courts ultimately held that even if there had been such a common law right, the enactment of the Statute of Anne had abrogated it for all published works. ${ }^{42}$ Such a right, had it existed, might have offered protection to unpublished scripts, but the British Parliament eventually decided that a play's first public performance should be equated with publication for copyright purposes. ${ }^{43}$

39. See, e.g., PATterson, supra note 25, at 47-78; Pamela Samuelson, Copyright and Freedom of Expression in Historical Perspective, 10 J. InTELL. Prop. L. 319, 323-38 (2003). Paying the owner of a manuscript was not, of course, the same as paying the author. See, e.g., LEO KiRSCHBAUM, SHAKESPEARE AND THE STATIONERS 5-7 (1955).

40. See PATTERSON, supra note 25, at 172-80; Rose, supra note 38, at 67-91.

41. See, e.g., DEAZley, supra note 36, at 73-74, 195-210; RONAN DEAZLEY, Rethinking Copyright 63-65 (2006); 1 William F. PAtry, Patry on Copyright \ $1: 11$ (2009); RosE, supra note 38, at 22 ("[T] here is no evidence that copyright was ever recognized as a common law right of an author in the sixteenth or seventeenth centuries."); Abrams, supra note 36, at 1134 ("As a matter of historical fact, the common law never developed any law of copyright.”). But see H. Tomás Gómez-Arostegui, The Untold Story of the First Copyright Suit Under the Statute of Anne in 1710, 25 BERKELEY TECH. L.J. 1249 (2010) (suggesting that complaints filed in Chancery before 1710 to vindicate stationer's copyright claims may provide some evidence of common law copyright).

42. Donaldson v. Beckett, 1 Eng. Rep. 837, 845 (1774); see DEAZLEY, supra note 36, at $191-220$.

43. 1842 Copyright Law Amendment Act, 5 \& 6 Vict. c. 45, § XX. The 1842 Copyright Law Amendment includes the first post-mortem copyright term, the first express workmade-for-hire provision, and the first compulsory license for reprinting out-of-print books. See generally Ronan Deazley, Commentary on Copyright Amendment Act 1842, PRIMARY SOURCES ON COPYRIGHT (1450-1900) (L. Bently \& M. Kretschmer eds., 2008), http://www.copyrighthistory.org/cgi-

bin/kleioc/0010/exec/ausgabeCom/\%22uk_1842\%22. Section 20 of the Act extended the dramatic performance right initially enacted in 1833 to musical compositions, and provided that "the first public Representation or Performance of any Dramatic Piece or Musical Composition shall be deemed equivalent, in the Construction of this Act, to the first Publication of any Book." The 1842 Act also permitted the registration of unpublished but publicly performed dramas and musical compositions, without depositing any copies, through recording the title, the name and place of abode of the author or composer, the name and place of abode of the copyright proprietor, and the time and place of the first public performance. 1842 Copyright Law Amendment Act, $₫$ XX. The Act also provided 
More fundamentally, however, proponents of common law copyright conceived of it as a printing right, limited to control over the printing and sale of copies. In the 18th century, not even the most ardent defender of common law copyright suggested it extended to control over public performances of works. ${ }^{44}$ Thus, a playwright's common law rights in a script, had they existed, would have empowered the dramatist to sell that script to a printer for publication, or withhold it from publication. It would have given the playwright no recourse, however, if players chose to perform the unpublished script without a license.

\section{A. English Theatre Before the Statute of Anne}

We tend to view historical facts through a contemporary lens. When we see a practice that looks familiar, we assume that its context must have matched, or at least resembled, its contemporary analog. Thus, much speculation about common law play right seems to begin by recognizing landmarks that would characterize such a right in recent times, and assuming the context must have followed familiar patterns. A serious exploration of the English theatre before the enactment of the Statute of Anne, though, reveals a context starkly different from one we would recognize. The most fundamental difference is the degree to which, from the 16th through the 18 th centuries, all aspects of theatrical performance were regulated by the crown. ${ }^{45}$ A monarchy that reacted to the seditious potential of the printing press by licensing all printing appreciated the subversive possibilities of public theatrical performance. ${ }^{46}$ The crown responded by criminalizing unlicensed theatrical presentations, limiting the legal theatres to companies owned and run by friends and courtiers, and requiring all scripts to be approved by the royal censor before the initial public performance. ${ }^{47}$ As the theatre in Tudor and Restoration England existed only by dint of royal privilege, the crown was called upon to decide disputes between rival theatres, and it did so: allocating plays, playwrights, or actors to one company

that the assignment of the right to print and public a script or musical composition did not also assign the public performance right unless it said so explicitly. Id. \ XXII.

44. See DEAZLEy, Rethinking, supra note 41, at 154-56.

45. See generally Oscar G. Brockett \& Franklin L. Hildy, History of the THEATRE 114-16, 211-14, 220-21 (9th ed. 2003).

46. John Russell Stephens, The Censorship of English Drama 1824-1901, at 7 (2010).

47. See, e.g., Judith Milhous, Theatre Companies and Regulation, in 2 THE CAMBRIDGE History of British Theatre 108 (Joseph Donahue ed., 2004) [hereinafter Milhous, Theatre Companies and Regulation]. 
rather than another. ${ }^{48}$ In that sphere, questions of common law literary property seem to be beside the point.

The Elizabethan and Restoration eras of British theatre history have been the subject of extensive study, but extrapolating from surviving documentary evidence requires guesswork and intuition. Current theatre historians have concluded that Elizabethan theatre companies paid playwrights for their services in essentially the same way they paid actors: playwrights received a salary, or participated as partners in the profits of the company, collecting a share of net receipts, or both. ${ }^{49}$ At least some playwrights (like actors and managers) who were "sharers" or partners in theatre companies were able to earn a living from the theatre, if not from writing plays. ${ }^{50}$ Play scripts were deemed to belong to the company, which decided when to produce them, revive them, or sell them to stationers for printing. ${ }^{51}$ After an initial reading of the script to the full cast, companies had scribes copy individual actors' "parts" or "sides" - pages interspersing a single actor's lines with a few words of cues from the end of the immediately preceding lines. ${ }^{52}$ Actors learned their lines from the parts, and did not see the entire play until they came together at the end of the rehearsal period for group rehearsal. ${ }^{53}$ Companies were reluctant to authorize printers to publish play scripts while

48. See, e.g., Judith Milhous, Thomas Betterton And the Management of LINCOLN's INN FIELDS 1695-1708, at 15-19, 66-68, 115-16, 201-02, 209-21 (1979) [hereinafter Milhous, Thomas BetTerton]; Judith Milhous \& Robert D. Hume, The Silencing of Drury Lane in 1709, 32 THEATRE J. 427 (1980) Thereinafter Milhous \& Hume, The Silencing of Drury Lane].

49. See Paulina Kewes, Authorship and Appropriation: Writing for the Stage IN ENGLAND 1660-1710, at 17 (2004); Judith Milhous \& Robert D. Hume, Playwrights' Remuneration in Eighteenth Century London, 10 HARV. LIBR. BULL. 1 (Summer-Fall 1999) [hereinafter Milhous \& Hume, Playwrights' Remuneration]; Mary I. Oates \& William J. Baumwol, On the Economics of the Theater in Renaissance London, 74 SwED. J. ECON. 136, 149, 156-58 (1972).

50. See, e.g., Peter Thompson, Shakespeare's Professional Career 27, 82-100 (1992); Peter Thompson, SHAKespeare's Theatre 19-35, 58-87 (2d ed. 1992).

51. Judith Milhous concludes that theatre companies treated the physical manuscripts of plays as carrying with them the license to produce them. MilHous, THOMAS BETTERTON, supra note 48, at 16-17. While one could argue that that practice manifests some precursor common law public performance right in unpublished scripts, the reason is likely more prosaic. Throughout this period, theatrical performances required a license from the Master of the Revels confirming that the play script had met the censor's approval. The Master of the Revels affixed his license stamp to the promptbook, so a company's possession of a promptbook with license stamp was essential evidence of the lawfulness of a production. See Joseph Loewenstein, Ben Johnson And Possessive Authorship 31 (2002).

52. See Tiffany Stern, ReHEARSAL From SHAKespeare to SHERIDAN 10-12, 149_ 51 (2000); Judith Milhous, The First Production of Rowe's "Jane Shore," 38 THEATRE J. 309, 312 (1986).

53. See STERN, supra note 52, at 61-79. 
they were still part of the active repertory, but were more eager to publish in years in which the theatres were closed because of political unrest, royal death, plague, or fire. ${ }^{54}$ Unauthorized printings were common and typically rife with errors.

The Protestant Revolution closed the theatres completely in 1642, and they remained closed until Charles II was restored to the throne in $1660 .^{55}$ King Charles granted royal patents ${ }^{56}$ to two courtiers to run theatre companies in London, and prohibited competing theatrical performances. ${ }^{57}$ Charles had enjoyed attending theatrical performances during his exile in France, and ordered his new English theatres to cast women in female roles, after the French fashion. ${ }^{58}$ The crown drew up a list of extant plays and allotted them exclusively to one company or the other, prohibiting each company from performing plays granted to the other. ${ }^{59}$ The division was unequal. Thomas Killigrew's King's Company received most of the popular plays. William Davenant's Duke's Company was less fortunate. ${ }^{60}$ Davenant, therefore, needed to commission new scripts. As the Duke's Company staged new plays, the King's Company found that it needed to find new

54. See LOEWENSTEIN, supra note 51, at 29-31; Milhous, ThOMAs BetTERTON, supra note 48, at 16-17; Milhous \& Hume, Playwrights' Remuneration, supra note 49, at 35. Scholars have surmised that some of the unauthorized editions were pieced together from actors' parts and actors' memory. See, e.g., GEORGE IAN DUTHIE, THE "BAD” QUARTO OF HAMLET: A CRitical Study 29-36 (1941); W. Mathews, The Piracies of Love a La Mode, 10 REV. Eng. Stud. 311, 315 (1934); see also 1 JOHn Bernard, Retrospections of the Stage 128 (Boston, Carter \& Hendee 1832).

55. During this period, theatre companies that had previously refused to publish their scripts made them available to printers. See KEWES, supra note 49, at 183.

56. Royal letters patent were monopoly privileges conferred by the king or queen. They were not limited to technological inventions. See generally CHRISTINE MACLEOD, INVENTING the Industrial Revolution: The English Patent System 1660-1800, at 10-39 (1988).

57. See Joseph Donahue, The Theatre from 1600 to 1800, in THE CAMBRIDGE HisTORY OF BRITISH THEATRE, supra note 47, at 3, 4-8. Ireland also had a single theatre company by dint of a royal patent granted in 1661. Scotland had none. See Gorel Garlick, Theatre Outside London, 1660-1775, in The CAMBridge History OF BRITISH TheATRE, supra note 47, at 165-70.

58. See generally Elizabeth Howe, THe First English ACTRESSES: WOMEN AND Drama 1660-1700, at 19-24 (1992); Milhous, ThOMAS BETTERTON, supra note 48, at 4-7.

59. See Robert D. Hume, Theatres and Repertory, in The Cambridge History OF BRITISH THEATRE, supra note 47, at 53, 55.

60. See KeWEs, supra note 49, at 13-15; Milhous, ThOmas BetTERTON, supra note 48, at 4-20. Killigrew's company had a much larger proportion of established actors who had been well-known before the revolution. Milhous speculates that Killigrew may have staked his claim to the lion's share of extant English repertory on the basis of his actors' prior connections to those plays. See id. at 17. 
scripts to compete for audiences. ${ }^{61}$ As before, the new scripts appear to have become the property of the company that first staged them. ${ }^{62}$ Playwright compensation, however, was no longer by salary or ownership share unless the playwright was also a member of the acting company. Rather, both companies appear to have settled on a compensation system under which the playwright would receive the net proceeds of a single performance, typically the third night, and, if the production proved to run longer than a few days, might be offered the net proceeds of an additional performance or two. ${ }^{63}$ While the benefit performance might earn a lot of money for an exceptionally successful play, the receipts were usually more modest. The division of the repertory between the companies meant that neither theatre company needed to worry that a competing theatre would perform its scripts. Perhaps as a result, the companies seem to have grown more interested in printing and publishing plays after their initial run. In at least some cases, the companies allowed the playwright to pocket the stationer's payment for the script. ${ }^{64}$ The amount of money printers paid for play scripts, though, was not substantial. ${ }^{65}$

Despite the royal constraints limiting competition, the two companies were unable to sustain their operations. By 1682, the King's Company was insolvent, and the Duke's Company absorbed its remnants, including its

61. See KEWES, supra note 49, at 13-20. Lacking a ready-made popular repertory, Davenant's Duke's company appears to have competed by offering productions featuring more impressive changeable scenery and special effects. See MiLHOUS, THOMAS BETTERTON, supra note 48, at 20-25. That strategy proved to be successful; Killigrew shortly had to build a new theatre to accommodate new audience demand for expensive sets. $I d$. at 12.

62. Robert D. Hume, The Rakish Stage: Studies IN ENGLiSh Drama 1660-1800, at 277 (1983); KeWES, supra note 49, at 15; Milhous, ThOMAs BETTERTON, supra note 48, at 15-16. Throughout this period, companies freely adapted plays in their repertory to respond to changing audience tastes, more stringent crown censorship, or changes in acting personnel.

63. See KEWES, supra note 49, at 13-20; Milhous \& Hume, Playwrights' Remuneration, supra note 49 , at 4 . Because the recipient of the benefit paid the costs attributable to that performance, managers could stage benefit performances at little risk to company finances. By the end of the 17th century, theatre companies also offered benefit performances to star actors, as bonuses in addition to or in lieu of salary. See Judith Milhous, United Company Finances, 1682-1692, 7 THEATRE RES. INT'L 37 (1982) (reconstructing the finances of the the theatre company formed in 1682 by combining the Kings Company and the Duke's Company into a single "United Company") [hereinafter Milhous, United Company Finances].

64. See Judith Milhous \& Robert D. Hume, Dating Play Premieres from Publication Data 1660-1700, 22 HarV. LiBr. Bull. 374, 395-96 (1974) [hereinafter Milhous \& Hume, Dating Play Premieres from Publication Data] (quoting Colley Cibber's 1696 contract).

65. See KEWES, supra note 49, at 24. 
theatre building and its repertory of plays. ${ }^{66}$ The United Company was now the sole licensed theatre in London, with an ample stock of established drama. The company's theatrical seasons were heavily dominated by revivals from that repertory, and it was well placed to turn a profit. ${ }^{67}$ The inheritors of shares of the patent for the original companies, now sharers in the United Company, were able to attract investors to buy their interests. ${ }^{68}$ The investors brought in new management with no theatrical experience. ${ }^{69}$ The new manager (a lawyer) sought to increase the United Company's profit margins, by reforming practices that seemed to him to be economically unsound. $\mathrm{He}$ sought to retire aging actors and cast younger performers in their roles, to present fewer shows, to reduce the compensation and benefits the company traditionally paid its actors, and to rein in spending for popular scenery and special effects. $^{70}$

The actors rebelled. In 1694, fifteen of the United Company's bestknown actors petitioned the Lord Chamberlain to hear their complaints, explaining that they found current management of the company was "soe intolerable \& heavy that unless relieved wee are not able to act any longer." "71 The Lord Chamberlain granted the rebels permission to withdraw from the United Company and form a rival company licensed to perform "all manner of Comdyes \& Tragedyes, Playes, Interludes \& Opera's and to performe all other Theatricall and musicall Entertainments of what kind soever." 72 The United Company got to keep the theatre buildings, costumes, sets, special effects equipment, and the Killigrew and Davenant patents, but its most famous actors had left, taking with them royal permission to perform any play in the United Company's repertory. ${ }^{73}$

66. See Milhous, Thomas Betterton, supra note 48, at 31-37. Milhous places most of the blame for the King Company's demise on Killigrew, whom she characterizes as a poor theatrical manager. Id. at 37.

67. See generally Milhous, United Company Finances, supra note 63, at 37 (assessing the "startling amount of money [that] flowed through the United Company").

68. See Milhous, Thomas Betterton, supra note 48, at 40-43, 51-62; Milhous, Theatre Companies and Regulation, supra note 47, at 114.

69. See Milhous, Thomas Betterton, supra note 48, at 59, 62; Paul Sawyer, Christopher Rich of Drury Lane: The Biography of a Theatre Manager 9-18 (1986).

70. See Milhous, Thomas BetTerton, supra note 48, at 59-66; Watson Nicholson, The Struggle for a Free Stage in London 7-9 (1966).

71. See The Petition of the Players, reprinted in Milhous, ThOmas BetTerton, supra note 48 , at $225,226$.

72. See Milhous, Thomas BetTerton, supra note 48, at 64-67.

73. See id. at 67-72. 
The rebel actors formed a rival company as an actors' cooperative, while the manager of the patent company continued to treat it as a business investment. $^{74}$ Both companies relied heavily on productions from their repertory, mounting relatively few new scripts. ${ }^{75}$ Occasionally they competed by trying to usurp one another's plays, ${ }^{76}$ but the strategy proved commercially unrewarding. ${ }^{77}$

Neither company prospered. The actors' company lacked the capital to build or renovate a suitable theatre, and its sharers, though famous, were aging. ${ }^{78}$ Meanwhile, whether because of mismanagement or fraud, the patent company was unable to pay its investors, its actors or its rent. ${ }^{79}$ Audience tastes were changing-increasingly, the crowds preferred spectacle, music, dance, and circus acts to drama or comedy. ${ }^{80}$ At the turn of the century, British moral reformers targeted theatres as particular dens of vice and indicted actors for onstage indecency. ${ }^{81}$ Both the actors' company and the patent company let bills go unpaid. Actors and investors complained that the managers of both companies were pocketing money rather than honoring their obligations. ${ }^{82}$

Queen Anne's Lord Chamberlain intervened repeatedly in efforts to reconfigure the two companies into a viable theatre. ${ }^{83}$ In 1708 , he reunited the acting company. He ordered that operas might be performed exclusively in one theatre, that tragedies and comedies might be performed exclusively in the other, and that nobody except for the managers of the two theatres

74. See Milhous, Thomas Betterton, supra note 48, at 68-97; Milhous, Theatre Companies and Regulation, supra note 47, at 114-15; SAWYER, supra note 69, at 25-31.

75. See Milhous, Thomas Betterton, supra note 48, at 97-112, 139-50.

76. Thus, in November of 1704 , both companies appear to have staged revivals of Shakepeare's Henry IV. See Season of 1704-1705, in 1 THE LONDON STAGE 1660-1800 PART 2: 1700-1729, at 179, 192, 195-96 (Judith Milhous \& Robert D. Hume eds., interim version 2001) (1960), available at http://www.personal.psu.edu/hb1/London\%20Stage \%202001/lond1704.pdf.

77. See Milhous, Thomas BetTerton, supra note 48, at 131-32, 174.

78. Id. at $88,113-24,161$.

79. Id. at 124-25, 154-68; SAWYER, supra note 69, at 40.

80. See Milhous, Thomas BetTerton, supra note 48, at 133-44, 188; SAWYer, supra note 69 , at $31-35,43-44$.

81. See Season of 1704-1705, supra note 76; Milhous, Theatre Companies and Regulation, supra note 47 , at 116

82. See Milhous, Thomas BetTerton, supra note 48, at 161-62, 167; Milhous, Theatre Companies and Regulation, supra note 47, at 117-18.

83. See NiCHOLSON, supra note 70, at 8-19; STERN, supra note 52, at 126-28. 
would be permitted to produce theatrical entertainment. ${ }^{84}$ The opera theatre soon found that its expenses dwarfed its receipts; the manager of the dramatic theatre refused to pay his actors full salaries. In 1709, the actors again petitioned the Lord Chamberlain to intervene. This time, the Lord Chamberlain ordered the patent theatre to close down. ${ }^{85} \mathrm{He}$ ousted the patent company's manager, and reorganized the company under different managers. To lessen inter-company competition, he restricted each company's performance dates. ${ }^{86}$

The picture that emerges from a look at 16th and 17th English century theatre history is of an industry closely supervised by the crown, which licensed theatre companies, play performance, and play printing, and intervened in disputes over repertory, personnel, performance schedule, competition, and compensation. Theatre managers valued playwrights as they valued actors, and paid them in the same fashion. Scripts once acquired entered a theatre company's repertory, where they could be revived, adapted, rewritten, performed, and printed without any further license from the writer. $^{87}$ Although there is some evidence suggestive of a custom that actors presumptively owned an interest in continuing to play the parts they had performed in the past ${ }^{88}$ the limited competition in the English theatre during these years, together with the royal restrictions forbidding actors to defect to rival companies without royal permission, make it difficult to verify whether the custom had much force. It seems clear, though, that at the time Parliament adopted the Statute of Anne, playwrights enjoyed no common

84. See Milhous, Thomas Betterton, supra note 48, at 189-221; Robert D. Hume, The Sponsorship of Opera in London 1704-1720, 85 MoD. PHILOLOGY 420, 423-29 (1988); Milhous \& Hume, The Silencing of Drury Lane, supra note 48, at 430-32.

85. See Milhous \& Hume, The Silencing of Drury Lane, supra note 48, at 435-40.

86. See id. at 435-47.

87. See, e.g., STERN, supra note 52, at 129-31, 241-45 (George Villier's The Rehearsal written in 1664 and then rewritten repeatedly between 1667 and 1776 to revamp its protagonist to parody different contemporary dramatists); see also COLLEY CiBBER, THE TragiCAL History OF KING RICHARD III (1700) (cut-and-paste job of Shakespeare's Henry VI and Richard III with Cibber's additional dialogue).

88. See STERN, supra note 52, at 149-51 (reporting that actors were deemed to own their parts); see also Milhous, ThOMAs BETTERTON, supra note 48, at 17 (reporting that in 1660 the King's company laid claim to most of the preexisting repertory on the ground that its veteran actors had performed those plays). The apparent custom may represent no more than the practical difficulty of preventing an actor from continuing to perform a role once she had memorized her part. But see Morris v. Kelly, 37 Eng. Rep. 451 (1820) (enjoining actress from performing play at a theatre other than the one that alleged ownership of the copyright and could prove ownership of the promptbook). 
law literary property right in their scripts, ${ }^{89}$ and the pervasive regulation of theatre left little room for such a right to arise.

The Statute of Anne made no immediate observable difference in the lot of dramatists.

\section{B. English Theatre From the StATUte of ANNE TO THE 1833 DRAMATIC LITERARY PROPERTY ACT}

Queen Anne died in 1714, to be succeeded by George I. The Hanover kings were not particularly interested in theatre, and actors were no longer deemed even honorary members of the royal household. ${ }^{90}$ Throughout the 18th century, small theatre companies sprang up to compete with the two patent theatres, but extensive government regulation and uncertain finances kept them from gaining a foothold. ${ }^{91}$ In 1737, Parliament passed the Licensing Act, which limited performance of legitimate drama to the two patent theatre companies and required that any script be vetted by the Lord Chamberlain before its first performance. ${ }^{92}$ Theatre historians report that the licensing act essentially shut down opportunities for playwrights to place new scripts, and many dramatists shifted their efforts to poetry or novels. Even

89. See, e.g., George Ticknor Curtis, A Treatise on the Law of Copyright 104-05 (1847); DEAZley, REthiNKING, supra note 41, at 155; 2 JAMES APPLETON Morgan, THE LAW OF LiTERATURE 286-87 (1875).

90. See, e.g., Hume, supra note 59, at 57.

91. See HuME, supra note 62, at 279-307. Debate over the continuing validity of the royal patents, which had not been officially confirmed by Parliament, apparently emboldened several managers to open unlicensed theaters in or near London. The holders of interests in the two theatre patents went to court repeatedly to close these efforts down and to prevent performers from defecting to unlicensed venues. See BROCKETT \& HiLDY, supra note 45, at 220-21. Further afield, a Dublin theatre successfully fended off a lawsuit seeking to enjoin its production of Sheridan's Duenna brought by the patent theatre that claimed to have purchased all rights froim Sheridan. See The Monthly Chronologer: Ireland Dublin, April 26, THE LONDON MAgazine, OR, GENTLEMEN's MONTHLy INTELligenCER, May 1770, at 279 (reporting Chancery decision that plaintiff was not entitled to an injunction). I am indebted to Tomás Gómez-Aroztegui for bringing this case to my attention.

92. Theatrical Licensing Act of June 21, 1737, 10 Geo. II c. 28. See David Thomas, David CARTER, \& AnNe Etienne, Theatre CENSORShip From WALPOLE TO Wilson (2007). According to Brockett, within a few years, managers began to evade the Licensing Act by selling tickets to concerts and offering dramatic entertainment for free. See BROCKETT \& HiLDY, supra note 45, at 221. By the 1780s, some of the larger towns outside of London had persuaded Parliament to license theatres in their towns, or empower local magistrates to do so. $I d$. 
though the vast majority of productions came from the extant repertory, though, the two patent companies produced several new scripts every year. ${ }^{93}$

With their opportunities at home constrained, some British actors formed companies to tour in the New World. Others sought to perform outside of London or in venues on the outskirts of the city, in competition with the patent companies, avoiding the prohibition by styling their productions as "concerts" or "burlettas" rather than dramas, comedies, or plays. $^{94}$

Toward the end of the 18th century, theatre companies began to contract with some authors to allow them to keep their statutory copyrights, and contract directly with stationers, in return for less money. ${ }^{95}$ In 1794, the two patent theatres started paying flat fees rather than benefits. ${ }^{96}$ Both companies had built larger houses to accommodate larger audiences, and they imposed the change to limit the amounts they needed to pay playwrights for new scripts. Historians Judith Milhous and Robert Hume have examined the account books of one of the patent theatres and concluded that, on average, playwrights collected more money under the new system than they would have under the old. ${ }^{97}$ By the end of the 18th century it was becoming possible for at least some playwrights to earn a living writing for the theatre.

\section{STATUTORY PLAY RIGHT IN ENGLAND}

Edward Bulwer-Lytton is known to modern American audiences as the author of the phrase "[i]t was a dark and Stormy night," and the namesake of an annual contest for overwrought prose. ${ }^{99}$ Bulwer-Lytton was a popular novelist, a poet, a baron, and a Member of Parliament. ${ }^{100}$ By the late 1820 s, the patent theatres were deeply in debt and smaller, competing theatres had

93. See Hume, supra note 59, at 67-70; HumE, supra note 62, at 307-11; Milhous, Theatre Companies and Regulation, supra note 47, at 108, 122-24.

94. See John Russell Stephens, The Censorship of English Drama 1824-1901, at 7-9 (1980).

95. See Milhous \& Hume, Playwrights' Remuneration, supra note 49, at 35-43; 3 Allardyce Nicoll, A History of ENGlish Drama 1660-1900, at 47 (1952).

96. House of Commons, Report From the SElect COMM. ON Dramatic LiTERATURE WITH MINUTES OF EVIDENCE (1832), http://www.copyrighthistory.org/cgibin/kleioc/0010/exec/ausgabe/\%22uk_1832\%22; Milhouse \& Hume, Playwrights' Remuneration, supra note 49 , at 6-7.

97. Milhouse \& Hume, Playwrights' Remuneration, supra note 49, at 26-27.

98. Edward George Bulwer-LytTon, Paul ClifFord 13 (1830).

99. THE Bulwer-LYTTON FICTION CONTEST, http://www.bulwer-lytton.com (last visited Feb. 15, 2010).

100. See generally Leslie Mitchell, Bulwer LytTon: The Rise AND FALL of A VICTORIAN MAN OF LETTERS (2003). 
sprung up. ${ }^{101}$ Licensed by the crown to perform musical entertainment and burlettas, they insisted that they could produce dramas, comedies, and melodramas so long as they interspersed them in bills with non-dramatic entertainment. The managers of the patent companies claimed that the nonpatent theatres bore significant responsibility for patent companies' financial troubles and pursued legal campaigns to shut the non-patent theatres down. ${ }^{102}$ In 1832, residents of London presented a petition protesting the prosecutions of upstart theatre companies. Bulwer-Lytton moved to establish a Select Committee on Dramatic Literature. ${ }^{103}$ Appointed chairman of the Committee, he held hearings, inviting testimony from playwrights, actors, managers, and government officials. ${ }^{104}$ The picture that the witnesses presented portrayed a lively environment of non-patent theatres operating under limited licenses but producing dramas and comedies in defiance of the patent companies' assertions of exclusive rights. ${ }^{105}$ Play scripts were readily available. In order to claim copyright under the extant statute, it was necessary to publish and register a play as a book. Once published, however, a play could be performed by any theatre that could get its hands on a script-the performance rights in published plays were universally understood to be in the public domain. ${ }^{106}$

When there had been only two theatre companies, the risk from competition was small, since the companies appear to have followed an informal practice of declining to poach each other's scripts or actors. In those circumstances, publication of a new play netted the company or playwright some extra money from the publisher without threatening performance revenues. As new theaters sprang up, though, they helped

101. See Jane Moody, The Theatrical Revolution, 1776-1843, in THE CAMBrIDGE History OF BRITISH THEATRE, supra note 47, at 199, 200-10.

102. See RePORT FROM THE SELECT COMm. ON DRAmATiC Literature, supra note 96, at 21-116; see, e.g., Morris v. Kelly, (1820) 37 Eng. Rep. 451. A complicating factor was that managers of the patent theatres mortgaged their shares and defaulted on the loans, giving creditors control of the companies. The creditors frequently failed to pay the actors what they had promised, so the actors had significant incentives to seek additional or alternative work. See id.

103. See Ronan Deazley, Commentary on Dramatic Literary Property Act 1833, Primary SOURCES ON COPYRIGHT (1450-1900) (L. Bently \& M. Kretschmer, eds., 2008), http://www.copyrighthistory.org/cgi-

bin/kleioc/0010/exec/ausgabeCom/\%22uk_1833\%22.

104. See id.; NiCHOLSON, supra note 70, at 325-34.

105. See generally RePORT From the SELECT COMm. ON DRAMATIC LiterATure, supra note 96 , at 9 (reproducing hearing transcripts).

106. E.g., DeAZley, RethinKING, supra note 41, at 154-55. 
themselves to the plays in the patent companies' repertories. ${ }^{107}$ Forgoing publication was no longer a feasible long term option: publishers were notorious for sending stenographers to attend unpublished plays and write down all the dialogue, so that they could publish unlicensed printed versions of the scripts. ${ }^{108}$ Since unpublished plays were not subject to copyright protection, the publishers risked little. ${ }^{109}$ Bulwer-Lytton asked all of his witnesses whether the theatre would be improved if the patent theatres lost their monopoly, and whether better plays would result if all theatre companies needed to compensate playwrights for performing plays. ${ }^{110}$ Witnesses answered variously, ${ }^{111}$ but Bulwer-Lytton intended to pursue both reforms.

In August of 1832, the Committee delivered a report calling for the expansion of copyright in dramatic literature to give writers control of public performances of their plays, and the termination of the patent theatres' monopoly. ${ }^{112}$ Both measures passed the House of Commons, but the House of Lords rejected the limitation on the patent theatres' monopoly, viewing the legislation as an affront to crown prerogative. ${ }^{113}$ As of 1833 , however, the Dramatic Literary Property Act ${ }^{114}$ enabled authors or their assignees to enjoin

107. See Report From the Select Comm. on Dramatic Literature, supra note 96, at 149 (testimony of David Edward Morris, proprietor, Haymarket Theatre).

108. See id. at 143 (testimony of Thomas Morton, reader, Drury Lane theatre); id. at 171 (testimony of Charles Mathews, proprietor, Delphi Theatre).

109. Authority on this point is not crystal clear. In Macklin v. Richardson, (1770) 27 Eng. Rep. 451, the author of the unpublished farce Love a la Mode had succeeded in enjoining the publication of the script in a magazine on the strength of his common law copyright in his unpublished script. Macklin was decided after the King's Bench decision in Milar v. Taylor, (1769) 98 Eng. Rep. 201, had recognized a perpetual common law copyright in printed, published texts that survived the Statute of Anne, but before the House of Lords' decision in Donaldson v. Beckett, (1774) 1 Eng. Rep. 837, rejected Milar v. Taylor. After Donaldson v. Beckett repudiated the notion of perpetual common law copyright in published texts, it would in theory have been possible to argue, as playwrights later did in the United States, that so long as the script remained unprinted and unpublished, the common law right had not been abrogated by the statute. The reported cases don't reflect such an argument's being made with success in the period between Donaldson and the 1932 hearings, and Parliament's later decision to equate performance with publication prevented the argument from succeeding later.

110. See, e.g., REPORT From the SELECT COMm. ON DRAMATIC LitERATURE, supra note 96, at 156-59 (testimony of Douglas Jerrold, author); id. at 170 (testimony of Charles Mathews, proprietor, Adelphi Theatre).

111. See, e.g., id. at 176 (testimony of W. Thomas Montcrieff, playwright); id. at 182 (testimony of George Bartley, actor).

112. Id. at 4-6.

113. See Deazley, supra note 103; Dewey Ganzel, Patent Wrongs and Patent Theatres: Drama and Law in the Early Nineteenth Century, 76 P.M.L.A. 384, 391-92 (1961).

114. 3 \& 4 Will.IV, c. 15 (1833). 
unlicensed productions. Despite the new law, play writing did not suddenly become more remunerative. First, both theatres and publishers claimed to be the authors' assignees in whom the new performance right vested. In Cumberland v. Planché, the court agreed that the publisher of the play owned the new performance right as part of its prior purchase of the copyright. ${ }^{115}$ As importantly, the overall economic climate for theatre in mid-19th century London was not at all playwright-friendly. ${ }^{116}$

In 1842, Parliament enacted a revised copyright statute, which provided that the dramatic performance right could be assigned separately from the copyright, ${ }^{117}$ and equated the first public performance of a dramatic work with publication. ${ }^{118}$ Literary property rights for plays were limited, at least from the time of the first public performance, to the rights available under the copyright statute. Even if one were to credit an argument that at some time in the past, dramatists in England, or the theatres they wrote for, could have claimed some literary property rights at common law to control the performance of their plays (and, as the past discussion indicates, I have concluded they could not), the enactment of the 1842 Act abrogated any such rights going forward. Since performance was the equivalent of publication for performance rights, and publication forfeited any nonstatutory copyright, British playwrights lost any common law public performance rights in their scripts upon the initial public performance.

\section{PLAY RIGHT IN AMERICA}

Across the Atlantic Ocean, the story developed differently. The early plot is similar. Congress enacted the first copyright statute in 1790, including only reproduction and distribution rights for books, maps, and charts. ${ }^{119}$ American publishers argued that that law did not abrogate their perpetual common law copyright. ${ }^{120}$ In Wheaton v. Peters, the Supreme Court held that it was doubtful

115. Cumberland v. Planché, (1834) 110 Eng. Rep. 1329; Deazley, supra note 103. Eight years later, Parliament enacted a revised copyright law that required assignment of the dramatic public performance right to be separately registered. See supra note 43 and accompanying text.

116. Deazley, supra note 103. Deazley suggests several reasons for the poor fortunes of dramatists following the enactment of the 1833 law, including poor management of theatre companies, high actor salaries and excessive production costs. Id.

117. See sources cited supra note 43.

118. British courts read the law to forfeit common law rights upon public performance even if that performance occurred in the United States. Boucicault v. Chatterton, (1867) 5 Ch.D. 267.

119. Act of May 31, 1790, at ch. 15, 1 Stat. 124.

120. See, e.g., Abrams, supra note 36, at 1178-85. 
that perpetual common law copyright had ever existed in England, but, if it had, the colonists didn't bring it with them when they emigrated to Pennsylvania, and, if they had, Congress had abrogated it for printed books when it enacted the 1790 Copyright Act. ${ }^{121}$ (And, had Congress not, the common law right had never been imagined to include public performance rights.) Dramatic works could be protected as books, and some were, but Congress did not add a dramatic performance right to the copyright law until 1856. ${ }^{122}$

\section{A. EARLY AMERICAN THEATRE}

Early American theatre was chiefly a British import. ${ }^{123}$ British actors formed touring companies to play in the New World, bringing their plays with them. ${ }^{124}$ Several American colonies, especially in the north, prohibited all theater as immoral, ${ }^{125}$ but the southern colonies were more receptive to visiting British performers. ${ }^{126}$ During the Revolution, the Continental Congress passed resolutions banning theatrical performances as displays of "extravagance and dissipation." 127 Once independent, the new country had no international copyright relations with any European nation. All British, French, and German scripts, therefore, were free for the taking. ${ }^{128}$ Most theatre performed in the United States during the first half of the 19th century was old British repertory, new British imports, and American adaptation of scripts that had succeeded in Britain, France, and Germany. Copying was the norm. ${ }^{129}$

121. Wheaton v. Peters, 33 U.S. (Pet. 8) 591 (1834).

122. Act of Aug. 18, 1856, 11 Stat. 138.

123. Alfred L. Bernheim, The Business of the TheAtre: An ECONOMic History OF THE THEATRE 1758-1932, at 5-7 (1932).

124. Id.

125. See id. at 6.

126. See id. at 6-7.

127. Resolution of Oct. 20, 1774, cl. 8.

128. See BERNHEIM, supra note 123, at 20. British courts, for their part, ruled that if a play was initially performed in America before being copyrighted in Britain, the initial performance should be deemed a foreign publication, which forever forfeited any British copyright. Boucicault v. Delafield, (1863) 71 Eng. Rep. 261; Boucicault v. Chatterton, (1877) 5 Ch.D. 267.

129. Thomas James Walsh, Playwrights and Power: A History of the Dramatists Guild 14 (1996); see Ben Graf Henneke, Laura KeEne: A Biography 51-52 (1990) (explaining that theatre managers and courts interpreted US law before 1856 to permit a manager "to produce any play in print without permission from, or fee to, the author so long as she named him”); THOMAS KITTS, THE THEATRICAL LiFE OF GEORGE HENRY BOKER 116-17 (1994) ("Most touring stars played published texts and were therefore not obligated to seek permission or pay royalties.”). 
It's not surprising that since America imported its actors and plays from England, it also imported its customary practices. Actors and managers claimed that their payment to a playwright for a script purchased all rights in the script unless a written contract reserved some printing or performance rights to the dramatist. ${ }^{130}$ Playwrights sold all rights in a script for an initial flat fee, and, sometimes, the promise of a benefit performance. ${ }^{131}$ The middle of the nineteenth century saw the rise of American dramatists and the immigration of British ones choosing to become American residents and citizens. Both groups of writers complained about their treatment under U.S. law as compared with the law of Britain or France. ${ }^{132}$

\section{B. The 1856 Dramatic COPYRIGHT ACT}

Nineteenth century American theatre involved artists who traveled frequently between the United States and Europe. English actors starred in American productions. American actors spent a season acting in London. American managers went to London or Paris to acquire scripts to adapt. ${ }^{133}$ Shortly after the enactment of the English Dramatic Literary Property Act in 1833, American writers began to lobby for a similar law here. ${ }^{134}$ Dion

130. See Clement E. Foust, The Life And Dramatic Works of Robert MONTGOMERY BIRD 145-47 (1919) (recounting Bird's consulting with lawyer in unsuccessful attempt to reclaim his copyrights from Edwin Forrest).

131. WALSH, supra note 129, at 10; see BERNHEIM, supra note 123, at 20 ("Payments to dramatists did not generally burden our managers of the first half of the nineteenth century.'); HENNEKE, supra note 129, at 129 (all rights to Our American Cousin purchased for $\$ 1000)$. Royalties were not unheard of: Henneke reported that Keene offered to pay royalties for American scripts as early as the mid 1850s, id. at 51-52, and George Henry Boker is believed to have demanded a $5 \%$ royalty on all performances of his plays from the $1850 \mathrm{~s}$ on. WALSH, supra, at 10-11. A royalty arrangement was not necessarily more remunerative. Boker's Leonor de Gurman opened in 1852 in Philadelphia to excellent reviews and then moved to Broadway. Kitts tells us that Boker's 5\% royalty on the initial run summed to \$159.09. KITTS, supra note 129 , at 87.

132. See generally Oren Bracha, Commentary on the U.S. Copyright Act Amendment 1856, Primary SOURCES ON COPYRIGHT (1450-1900) (L. Bently \& M. Kretschmer eds., 2008), http://www.copyrighthistory.org/cgi-

bin/kleioc/0010/exec/ausgabeCom/\%22us_1856\%22; sources cited infra note 134.

133. See, e.g., 1 The Cambridge History of American Theatre 7-16 (Christopher Bigsby \& Don B. Wilmeth eds., 1999); Simon E. Williams, European Actors and the Star System in the American Theatre 1752-1870, in The CAMBridge History OF AMERICAN THEATRE, supra, at 303; infra notes 134-35, 147-68 and accompanying text.

134. See FOUST, supra note 130, at 147-51; KITTS, supra note 129, at 116-18. Two of the most prolific and litigious playwrights of the 19th century were Dionysus Boucicault, an Irish playwright who became an American citizen, and Augustin Daly, a theatre manager from North Carolina. Boucicault and Daly collided in the most famous of 19th century us copyright cases, Daly v. Palmer, 6 F. Cas. 1132 (C.C.S.D.N.Y. 1868), in which the court found that Boucicault, the author of After Dark, had plagiarized the railroad rescue scene 
Boucicault, an Irish playwright who later became a U.S. citizen, claimed at least partial credit for persuading the U.S. Congress to enact the 1856 Dramatic Copyright Act during his initial tour of the States. ${ }^{135}$ Boucicault may have had some role in acquainting home-grown authors of the differences between U.S. and European laws. The work of persuading Congress, though, appears to have been shouldered by American-born writers George Henry Boker, Robert Taylor Conrad and Robert Montgomer Bird, who convinced Senators Charles Sumner and William Seward to shepherd a bill through the Senate. ${ }^{136}$ The 1856 Act gave the author or proprietor of a copyrighted work, or his heirs or assigns, "the sole right . . to act, perform, or represent" the work. ${ }^{137}$ As with its British counterpart, the act was initially invoked to vindicate the rights of authors' assignees. ${ }^{138}$

\section{COMMON LAW Rights}

In another part of the forest, the 19th century also saw the rise of the American legal treatise. ${ }^{139}$ Early treatises were essentially case digests, but their authors began to view their task more ambitiously. 19th century legal treatises sought to organize and explicate entire regions of law, usually by aligning their principles with the principles of natural law. ${ }^{140}$ The first U.S.

from Daly's Under the Gaslight. Together with Laura Keene, an expatriate Briton who became an American theater manager, and Charles Frohman, an American theatre manager who cornered the market for U.S. rights to produce of British scripts, they were responsible for most of the theatre-related copyright litigation in the 19th and early 20th century.

135. See Dion Boucicault, Leaves from a Dramatist's Diary, 149 N. AM. REV. 228, 230 (1889). Oren Bracha doubts that Boucicault had much to do with it. See Bracha, supra note 132. Bracha notes that contemporary sources credit playwrights George Henry Boker, and Robert Montgomery Bird and New York Senator William Henry Seward as the forces behind the amendment. Id. Dr. Bird wrote to Boker in 1853 to encourage his efforts to persuade Congress to enact a dramatic copyright bill, but it is unlikely that he was directly involved in drafting the bill. Bird's health was poor, and he died in 1854. See FOUST, supra note 130, at 147-50 (reprinting letter); id. at 150-52 (describing Bird's final illness and death). Bracha speculates, however, that Bird might have been behind an 1841 effort to secure performance rights for playwrights. Bracha, supra note 132. Boucicault also claimed to have established the entitlement of European playwrights to royalties for performances of their plays. See Boucicault, supra, at 229.

136. See KITTS, supra note 129, at 118-26; Dramatic Copyright, N.Y. TIMES, Aug. 1, 1856, at 4.

137. Act of Aug. 18, 1856, 11 Stat. 138, 139.

138. See, e.g., Martinetti v. Maguire, 16 F. Cas. 920 (C.C.D. Cal. 1867); Roberts v. Myers, 20 F. Cas. 898 (C.C.D. Mass. 1860).

139. A.W.B. Simpson, The Rise and Fall of the Legal Treatise: Legal Principles and the Forms of Legal Literature, 48 U. CHI. L. REV. 632, 671-74 (1981).

140. Id. 
copyright treatise is usually deemed to be Curtis's. ${ }^{141}$ Curtis articulated a natural rights basis for literary property, deriving from the author's initial exclusive possession of the work that he created. Curtis insisted, however, that the right was inherently limited to "the exclusive multiplication of copies of that particular combination of characters, which exhibits to the eye of another the ideas that he intends shall be received."142 The legislative truncation of its term (from forever to a term of years) was appropriate, he wrote, because after two or three generations, administering it would be too difficult for society to tolerate. ${ }^{143}$ Curtis also thought that a dramatist's common law right in a published play would not extend to "the sole right of presentation upon the stage."144

The first reported American cases claiming common law performance rights in plays followed the enactment of a statutory performance right for dramatic works and were initially cast as copyright suits brought under the provisions of the 1856 Act. Plaintiffs claimed copyrights in their plays, but had failed to satisfy the statutory prerequisites. The earliest cases excused the failure to meet statutory formalities, ${ }^{145}$ but later courts held that the statute's performance right was available only for properly registered works that met all statutory requirements. ${ }^{146}$

141. CURTIS, supra note 89. Curtis's treatise was later plagiarized by the Bristish treatise author Walter A Copinger, who liberally incorporated Curtis prose into his 1870 book, COPINGER's LAw OF COPYRIGHT. See id.; Ronan Deazley, Commentary on Copinger's Law of Copyright (1870), PRIMARY SOURCES ON COPYRIGHT (1450-1900) (L. Bently \& M. Kretschmer 2008), eds., http://www.copyrighthistory.org/cgibin/kleioc/0010/exec/ausgabeCom/\%22uk_1870\%22. Because negotiations on international copyright protection had stalled, there was not yet anything illegal about such appropriation.

142. CURTIS, supra note 89, at 13.

143. Id. at 24 .

144. Id. at 104 .

145. See Roberts v. Myers, 20 F. Cas. 898, 899 (C.C.D. Mass. 1860).

146. The 1831 Copyright Act made copyright available to authors who were U.S. citizens or residents, or the authors' assigns, upon recording of the title of the work, deposit of the title page before publication, publication, payment of a fifty-cent recording fee, notice inserted on the title page of all published copies, and deposit within three months of publication of a copy of the work with the clerk of the court. Act of Feb. 3, 1831, at ch. 16, 4 Stat. 436 \S 1, 4, 5. Congress replaced the 1831 Act with the general revision of 1870. The major innovations of the 1870 Act were transferring registration and recording functions from the clerks of the courts to the Library of Congress, and expanding copyright rights to allow authors to reserve the exclusive right to dramatize or translate their own works. Copyright remained available only to authors (or the assigns of authors) who were U.S. citizens or residents, and continued to require recordation, a fifty-cent fee, publication, deposit, and notice as prerequisites. Act of July 8, 1870, ch. 230, 16 Stat. 198 SS 86, 90, 92, $93,97$. 
Dion Boucicault followed the practice of registering and depositing the title page of his plays without publishing his scripts. ${ }^{147}$ In England, this would have sufficed to secure statutory copyright. ${ }^{148}$ In the United States, however, most courts ultimately insisted that the publication of printed copies was a condition of statutory copyright. ${ }^{149}$ Early suits to enforce the new performance right succeeded even with defects in copyright registration. In Roberts v. Myers, the purported assignee of Dion Boucicault's copyright in The Octoroon sought a preliminary injunction under the 1856 Act to prevent an unlicensed production. ${ }^{150}$ It transpired that Bouccicault had registered the title page of the play with the clerk of the court, but neglected to deposit the required printed copies. ${ }^{151}$ Indeed, he had not yet published the play. Judge Sprague read the statutory language to permit him to grant the preliminary injunction: "The statute requires that such copy shall be deposited within three months after publication. That time has not arrived. There has been no publication." $" 152$

In a later lawsuit over the same play, the judge expressed more concern that Boucicault had not perfected his statutory copyright. ${ }^{153}$ Judge Shipman nonetheless read Roberts v. Myers to stand for the proposition that Boucicault could either rely on a statutory copyright or he could recover on the basis of common law rights in his unpublished manuscript. ${ }^{154}$ In Boucicault v. Hart, however, Judge Hunt ruled the purported copyright registration of another Boucicault play invalid. The judge explained:

[T] o secure a copyright of a book or a dramatic composition, the work must be published within a reasonable time after the filing of

147. See, e.g., Boucicault v. Wood, 3 F. Cas. 988 (C.C.N.D. Ill. 1867); Boucicault v. Fox, 3 F. Cas. 977 (C.C.S.D.N.Y. 1862). See also supra notes 134-35 and accompanying text. Dionysus Boucicault was an extremely prolific playwright born in Ireland who immigrated to the United States in the latter half of the 19th century. Copyright nerds know him as the author of After Dark, the play found to have plagiarized the railroad rescue scene from Under the Gaslight. See Brady v. Daly, 175 U.S. 148 (1899); Daly v. Webster, 56 F. 483 (2d Cir. 1892); Daly v. Palmer, 6 F. Cas. 1132 (C.C.S.D.N.Y. 1868). Both Boucicault and Daly faced multiple charges of plagiarism in their careers. Many of their plays were adapted or revised versions of material written by others.

148. See supra note 43 .

149. Koppel v. Downing, 11 App. D.C. 93 (1897); Carillo v. Shook, 5 F. Cas, 68 (C.C.S.D.N.Y. 1876); Boucicault v. Hart, 3 F. Cas. 983 (C.C.S.D.N.Y. 1875); Benn v. LeClercq, 3 F. Cas. 201 (C.C.D. Mass. 1873). But see Roberts, 20 F. Cas. at 899 (enjoining performance of unpublished script).

150. Roberts, 20 F. Cas. at 899.

151. Id. at 898-99.

152. Id. at 899 .

153. Boucicault v. Fox, 3 F. Cas. 977 (C.C.S.D.N.Y. 1862).

154. Id. at $980-81$. 
the title page, and two copies be delivered to the librarian. These two acts are, by the statute, made necessary to be performed, and we can no more take it upon ourselves to say that the latter is not an indispensable requisite to a copyright, than we can say it of the former. ${ }^{155}$

Finding that Boucicault had failed to secure a copyright in his play, the court dismissed the case. Judge Hunt expressed the view that defendant had invaded Boucicault's "common law right of ownership in his dramatic composition." Because the parties were citizens of the same state, though, the federal court had no jurisdiction to grant the remedy to which Boucicault was entitled under common law. ${ }^{156}$

Laura Keene, a New York actor-manager and the assignee of the American rights to Tom Taylor's Our American Cousin, ${ }^{157}$ sued a competitor under the copyright statute to enjoin an unlicensed performance. The court found Keene's copyright invalid because it derived from an author who was neither a citizen nor a resident of the United States. ${ }^{158}$ The court allowed Keene to recover damages on a breach of confidence theory: defendants had suborned one of Keene's actors and caused him to reveal all of the alterations Keene had made to the script and all of the stage business performed in her production. ${ }^{159}$

As an alternative ground, the court suggested, Keene should be able to recover on a common law literary property theory. ${ }^{160}$ The common law cause of action Judge Cadwalader announced was peculiarly cramped. If the

155. 3 F. Cas. 983, 986 (C.C.S.D.N.Y. 1875); accord Koppel v. Downing, 11 App. D.C. 93 (1897); Carillo v. Shook, 5 F. Cas. 68 (C.C.S.D.N.Y. 1876); Benn v. LeClercq, 3 F. Cas. 201 (C.C.D. Mass. 1873).

156. Boucicault, 3 F. Cas. at 987-88. The December 17, 1876 issue of the New York Times reports that the case settled out of court. Court Notes, N.Y. TIMES, Dec. 17, 1876, at 10.

157. The play is best known for being the play being performed at the Ford Theatre the night that John Wilkes Booth assassinated President Lincoln.

158. Keene v. Wheatley, 14 F. Cas. 180, 185, 191 (C.C.E.D. Pa. 1861). Taylor was British. Keene was not yet an American citizen but had been a U.S. resident for many years. She had registered the copyright under the title Our Country Cousin, in her own name as proprietor on October 2, 1858. See HeNNEKE, supra note 129, at 91, 129-43. (Keene had also failed to publish the script as a printed book and deposit copies with the clerk of the court, but the judge excused that on the same reasoning adopted in Roberts v. Myers, see Keene, 14 F. Cas. at 185). Contemporary legal writers interpreted the opinion to hold that a resident alien could not copyright the works of a non-resident alien. See James Appleton Morgan, An International Copyright Law, 3 FORUM 35, 37-38 (1875). Professor Henneke claimed that the case motivated Keene to become a naturalized US citizen to avoid future copyright problems. See HENNEKE, supra note 129, at 111.

159. HeNNEKE, supra note 129, at 188.

160. Keene, 14 F. Cas. at 201-08. 
proprietor of a play authorized publication, and the printed script enabled a competitor to mount an unlicensed performance, then, absent statutory copyright, the performance was not actionable. Similarly, if the proprietor authorized a public performance, and that performance enabled an unlicensed production, that production was lawful unless the proprietor had a valid statutory copyright in the script. Where, however the public performance was not what enabled the defendant to present an unauthorized production, the proprietor's reserved literary property rights would support a lawsuit. ${ }^{161}$

Keene then filed a state court action to enjoin a second unlicensed production of Our American Cousin at the Boston Museum, relying on Massachusetts common law. ${ }^{162}$ The state court cited Judge Cadwalader's analysis with approval, but dismissed the case nonetheless, holding that

These principles sustain the demurrer to the plaintiff's bill. She has publicly represented the play, Our American Cousin, before audiences consisting of all persons who chose to pay the price charged for admission to her theatre. She has employed actors to commit the various parts to memory; and unless they are restrained by some contract, express or implied, we can perceive no legal reason why they might not repeat what they have learned, before different audiences, and in various places. If persons, by frequent attendance at her theatre, have committed to memory any part or the whole of the play, they have a right to repeat what they heard to others. We know of no right of property in gestures, tones, or scenery, which would forbid such reproduction of them by the spectators as their powers of imitation might enable them to accomplish. ${ }^{163}$

161. Id. at 207.

The case recapitulated stands thus: The complainant having the literary proprietorship of this comedy, but no statutory copyright in it, and having publicly performed it at her theatre, with an intention to continue its public performance there, the defendants, against her will, performed it repeatedly at their theatre, without having been, directly or secondarily, enabled so to do through its impression upon the memory of any of her audience. This was an infraction of a proprietary right retained by the complainant. Independently also of such right, she is entitled to redress, because the defendants enabled themselves to represent the play by knowingly taking advantage of a breach of confidence committed by a person in her employment.

Id.

162. Keene v. Kimball, 82 Mass. (16 Gray) 545 (1860).

163. Id. at 551 . 
Crowe v. Aiken ${ }^{164}$ involved a second Tom Taylor script, this one titled Mary Warner. Taylor wrote the play for the actress Kate Bateman, and assigned the U.S. stage rights to her husband. ${ }^{165}$ After Bateman performed the play in London, she and her husband traveled to New York and performed the play there. Neither Taylor nor plaintiff's husband sought registration under the U.S. copyright statute, nor authorized the play's publication. Defendant purchased a copy of the script and sought to stage the play in Chicago. Bateman's husband sued to enjoin him, "based not upon any copyright statutes, but on the principles of the common law and of equity." Judge Drummond examined the copy of the script, and found it suspicious. "It is not in the usual form of a published play, but consists of printed slips fastened together in pamphlet form, with plats and stage directions as if for dramatic use only."166 Concluding that the defendant's script was created in some unauthorized or wrongful way, and not by memory only, the court entered a preliminary injunction. ${ }^{167}$

Finally, in 1878, a New York trial court enjoined a San Francisco production of an unpublished English adaptation of a French play at the behest of the assignee of the assignees of the British adapters, relying on the common law rights attaching to unpublished manuscripts. ${ }^{168}$

164. 6 F. Cas. 904 (C.C.N.D. Ill. 1870).

165. Why the husband? Parliament didn't enact the Married Women's Property Acts until later. See Married Women's Property Act, 1870, 33 \& 34 Vict., c. 93 (Eng.); Married Women's Property Act, 1882, 45 \& 46 Vict., c. 75 (Eng.).

166. Id. at 905 .

167. Id. at 907. The rule that it was not copyright infringement to reproduce a script from memory (as distinguished from stenography or purloined parts) persisted, showing up in statutory as well as non statutory play right cases. See, e.g., Shook v. Rankin, 21 F. Cas. 1337 (C.C.D. Minn. 1875). The durability of the rule supports an inference that many 19th century courts continued to view copyright as conferring rights related to making and distributing material objects rather than rights in intangible works of authorship. For a different piece of evidence supporting that inference, see Edward S. Rogers, The Law of Dramatic Copyright, 1 MiCH. L. REV. pt. 2, 179, at 184 (1902) (“The reason why public performance of an unpublished uncopyrighted play is not a dedication, may be very briefly stated: The author does not part with his manuscript, and no copies are made so that the public can have access to the work itself.").

168. French v. Maguire, 55 How. Pr. 471 (N.Y. Sup. Ct. 1878). The plaintiff, Samuel French, founded the Samuel French dramatic licensing agency in 1830. See SAMUEL FrENCH, INC., http://www.samuelfrench.com (last visited July 31, 2010). Other cases during this time frame upheld common law first printing rights for unpublished manuscripts. See, e.g., Palmer v. DeWitt, 47 N.Y. 532 (1872) (upholding an injunction against the printing of an unpublished play). 
Copyright Office records before 1978 are neither as complete nor as reliable as one might wish, ${ }^{169}$ but a Copyright Office publication listing every dramatic composition registered between 1870 and 1916 suggests that many dramatists may have sought to register their copyrights without publishing their scripts, despite the fact that the statute did not permit it until 1909. The preface explains:

Under the legislation in force from July 8, 1870 to July 1, 1909, it was customary to file the title-page of the drama in advance of the deposit of copies and subsequently deposit the required copies. The result has been that a great many titles were filed for registration which were not followed by the deposit of copies. This was especially so in the case of dramas, and it is estimated that in more than 20,000 cases, while the title has been recorded, no copies have been received. ${ }^{170}$

We don't know how many of those 20,000 plays were claimed by authors or proprietors who didn't know they needed to print, publish and deposit copies to perfect their rights, how many were deliberately not published to discourage unlicensed performance, and how many simply went through a title change before they were finalized. It seems likely, though, that Boucicault, Keene, and Bateman were not alone in believing themselves to have secured federal copyright protection. ${ }^{171}$

Thus, by the late-1870s, the health of a common law public performance right in plays was not yet robust. The claim that common law literary property extended far enough to permit dramatists and their assigns to control public performances had initially been raised as an afterthought to failed statutory copyright claims. ${ }^{172}$ Courts had recognized common law

169. See Robert Brauneis, Copyright and the World's Most Popular Song, 56 J. COPR. SOC'Y 335, 423-26 (2009).

170. 1 Library of Cong. Copyright OfFice, Dramatic Compositions COPYRIGHTED IN THE UNITED STATES 1870 TO 1916, at i (1918).

171. See also Frankel v. Irwin, 34 F.2d 142, 143 (S.D.N.Y. 1918) (dismissing suit for infringement of "unprinted play, copyrighted in 1901" on other grounds).

172. During the same fifteen-year time period, only five reported cases with copyrights adjudged to be satisfactory sought to vindicate the 1856 performance right for plays. Three of the five involved unpublished Dion Boucicault plays. See Boucicault v. Wood, 3 F. Cas. 988 (C.C.N.D. Ill. 1867); Boucicault v. Fox, 3 F. Cas. 977 (C.C.S.D.N.Y. 1862); Roberts v. Myers, 20 F. Cas. 898, 899 (C.C.D. Mass. 1860). One, the infamous Daly v. Palmer, 6 F. Cas. 1132 (C.C.S.D.N.Y. 1868), involved a copyright in a published play claimed by an American playwright. The fifth involved a translation of a French play that appears not to have been published in print. The assignees of the copyright produced a copyright certificate and an assignment from the copyright proprietor, and neither defendants nor the court appear to have raised the issue of invalidity due to the failure of the registrant to publish and deposit copies. See Shook v. Rankin, 21 F. Cas. 1337 (C.C.D. Minn. 1875). Evidence from published 
performance rights where statutory copyrights were defective, but cabined them with odd limits. Few cases had arisen, and no general rule had yet presented itself. ${ }^{173}$ Eaton Sylvester Drone, though, was about to publish a magisterial treatise that would change that.

\section{Eaton Drone's Natural Law Play Right}

Thirty years after Curtis's treatise, Eaton Drone published his thicker treatise. His goal was more ambitious than Curtis's:

The task of the juridical writer is to set forth the true principles which govern the law; to point out the proper meaning of the statutes; to show what decisions are rights and what are wrong; to explain what is doubtful or obscure; and, generally, to give the law in a form as true, clear, systematic and harmonious as it is in his power to do. He is without authority to say what construction shall be given to statutes, and he is without power to overrule erroneous decisions. But he may point out the true meaning of the law, and show wherein it has been wrongly interpreted. When this has been done, the judicial affirmance of what is right and the rejection of what is wrong will be in many cases but a question of time. ${ }^{174}$

Drone's view of the scope of copyright law was more capacious than the narrow right described by Curtis. ${ }^{175}$ Drone's theory was that literary property rights were natural rights, and, as such, both perpetual and without limitation. ${ }^{176}$ Such rights could be expressly abrogated by statute, but not by courts. ${ }^{177}$ Beginning with the premise that the author's natural right to his literary property comported with the best theoretical principles and had not been effectively disproved by its doubters, he then considered whether proponents of any restriction of those common law rights had made an effective case for the validity of the limitation. ${ }^{178}$ Drone rejected as illreasoned cases like Donaldson v. Beckett, ${ }^{179}$ Wheaton v. Peters, ${ }^{180}$ and Stowe v.

copyright office records suggests that many playwrights and their assignees continued to register the title of their plays without perfecting their copyright with publication and deposit of copies. See supra text accompanying note 170.

173. See generally MORGAN, supra note 89, at 267-370 (summarizing cases); Herman F. Selvin, Should Performance Dedicate?, 42 CALIF. L. REV. 40, 48-50 (1954).

174. DRONE, supra note 1 , at vii.

175. Compare, e.g., id., at 2-26, with CuRTIS, supra note 89, at 5-25.

176. DRONE, supra note 1, at 8-20, 101-15.

177. Id. at 20-26, 116-27.

178. See, e.g., id. at 22-26, 47-53; see also R.R. BOWKER, COPYRIGHT: ITS LAW AND LITERATURE 2 (1886) ("Property right in unpublished works has never been effectively questioned - a fact which in itself confirms the view that intellectual property is a natural inherent right.").

179. (1774) 1 Eng. Rep. 837; see DrONE, supra note 1, at 42-43. 
Thomas. ${ }^{181}$ Unfortunately, he explained, the British Parliament had abrogated playwrights' common law rights in England by declaring that public performance amounted to publication. ${ }^{182}$ The United States Congress, however, had not yet done any such thing, and indeed, the Octoroon case had held that performance is not publication. ${ }^{183}$ Thus, Drone argued, common law play right survived in all its glory. ${ }^{184}$

Drone's treatise sought to be comprehensive. It was nearly 800 pages long, and cited and discussed most of the copyright cases ever decided. Drone, did not, however, rely on judicial reasoning to tell him what the law was. Rather, he derived what the law should be from first principles of natural law, and then criticized the cases that departed from it. ${ }^{185}$ That allowed him to expound on the proper scope of common law play right, and the proper scope according to Drone was exceptionally broad. ${ }^{186}$

Here, for example, is Drone on the effect of public performance on common law rights:

The true principle which governs the question relating to the effect of public representation on the owner's exclusive rights in a manuscript dramatic composition has been wholly overlooked in the recent judicial discussions of the subject. If such rights are lost, restricted, or prejudiced by public representation, it must be either by force of the common law or by operation of some statute. It has been shown elsewhere in this work that by the common law no rights in an intellectual production are forfeited by a publication of any kind. The property in a literary work is not, by the common law, prejudiced even by its publication in print. As far as the common law is concerned, the owner's rights are the same after publication in print as they were before. The now settled doctrine that there can be no copyright after publication except under the

180. 33 U.S. 591 (1834); see DRONE, supra note 1, at 43-48.

181. Stowe v. Thomas, 23 F. Cas. 201 (C.C.E.D. Pa. 1853); see DronE, supra note 1, at $450-55$.

182. DRONE, supra note 1 , at 575-76.

183. Id. at 555 (citing Boucicault v. Fox, 3 F. Cas. 977 (C.C.S.D.N.Y. 1862)).

184. Drone, supra note 1, at 573-74. Common law play right cases, Drone cautioned, could be brought only in state court unless diversity existed. Id. at 585 .

185. Thus, Drone spent four pages discussing opinions stating that it was lawful to perform a play if one reproduced it entirely from memory, DRONE, supra note 1, at 558-62, and seven pages refuting the reasoning underlying the distinction, $i d$. at 566-72.

186. E.g., id. at 565-74, 582-84. Contemporary reviews criticized Drone for elevating his own theories over judicial decisions. See Culture and Progress: Drone on Copyright, 17 SCRIBNERS MONTHLY 911 (Feb. 1879) ("Mr Drone has no slavish reverence for precedents; he reverses decisions right and left."); Mr. Drone's Treatise on Copyright, 6 INT'L REV. 699, 702 (1879) (“The chief difficulty ... is that he does not, for a lawyer, sufficiently distinguish between his own views of what the law ought to be and what the courts have declared it to be."). 
statute is based on the ground, not that publication is by the common law an abandonment of the author's rights, but that the common law property in a published work is taken away by operation of the statute.

It is then clear, both on principle and authority, that the property in a manuscript play is not injuriously affected by authorized public representation, unless by the operation of some statute. Now, in the United States, there is no statute which can have this effect, because there has been no legislation relating to manuscript dramatic compositions. Statutory playright is secured in published compositions alone, and representation is not publication within the meaning of the statute. When a dramatic composition is published in print, the owner's common-law rights are destroyed by operation of the statute, to which he must look for protection. But property in a manuscript play is governed exclusively by the common law, and is in no wise affected by any statute. Hence in the United States, the owner's rights in a manuscript play are not prejudiced by its authorized public representation. ${ }^{187}$

Armed with Drone's analysis, the proprietors of scripts filed suit in state court (claiming ownership by assignment of playwright's rights). ${ }^{188}$ Courts followed Drone. Drone originated the name of "playright." He also invented its scope. ${ }^{189}$

In Tomkins $v$. Halleck, ${ }^{190}$ the Massachusetts Supreme Court reexamined its ruling in Keene v. Kimball, and overruled it. ${ }^{191}$ Orlando Tompkins, one of the managers of the Boston Theatre, purchased the exclusive right to present a British melodrama in New England from its New York producer, who had bought American rights and commissioned a revision to suit American audiences. ${ }^{192}$ During the play's New York run, two individuals ("one Byron

187. Drone, supra note 1 , at 574.

188. Drone advised that the owner of the common law playright in an unpublished play could transfer his or her rights "either in whole or in part . . by parol." Id. at 581.

189. Thus Drone concluded, on the basis of reasoning not clear to me, that the authorized print publication of a manuscript play anywhere in the world would abrogate the common law play right of a U.S. rights holder who purchased his exclusive rights prior to the publication. See Drone, supra note 1, at 577-83. When such a case arose, the New York State court followed Drone, and held that the common law rights in the manuscript play had been destroyed by a subsequent German publication. Daly v. Walrath, 57 N.Y.S. 1125 (App. Div. 1899).

190. 133 Mass. 32 (1882).

191. Id. at 46.

192. The World, a melodrama by Paul Merrit, Henry Pettit, and Augustus Harris, received an elaborate production that ran from March 21, 1882, for eleven weeks. Orlando Tomkins was the senior manager of the Boston Theatre. EugEnE TOMKIns, THE BOSTON THEATRE 
and one Mora") attended the play repeatedly. Byron memorized as much as he could, and dictated his recollection to Mora. ${ }^{193}$ Byron sold the resulting script to Thomas Halleck, who produced it at his Alhambra Theatre. Tompkins filed suit in state court against Halleck, who insisted that reproducing a script from memory, as Byron and Mora had done, was expressly permitted by Keene v. Kimball. Noting Drone's objection that the privilege to reproduce from memory made no sense, the court repudiated the exception. ${ }^{194}$

The most Drone-ish common law play right decision is the United States Supreme Court's opinion in Ferris v. Frohman, decided in $1912 .{ }^{195}$ The case concerned a melodrama, The Fatal Card, written by British authors Charles Haddon Chambers and BC Stephenson, performed in London in September of 1894. The authors registered their British copyright in the play in November of 1894 at Stationers Hall. American manager Charles Frohman bought the rights of one of the coauthors, and produced it first in New York and then as a touring production. ${ }^{196}$ George MacFarlane adapted the British play and sold it to theatre manager Richard Ferris, who registered the copyright in the adaptation. ${ }^{197}$ Ferris's production of the MacFarlane

1854-1901, at 290 (1908). Thomas Halleck was the proprietor of the Alhambra Theatre, also in Boston. Donald C. King, The Theatres of Boston: A Stage and SCReEn History 67-68 (2005).

193. Tomkins, 133 Mass. at 32.

194. Id. at 43-44.

195. Ferris v. Frohman, 223 U.S. 424 (1912) (applying pre-1909 Act law).

196. See New Bills of the Week, N.Y. TimeS, Dec. 30, 1894, at 10; The Fatal Card Tonight, DAily KenneBEC J., Dec. 1, 1895, at 1, col. 4; Theatrical Gossip, N.Y. Times, Jan. 14, 1895, at 8. Ultimately, Frohman licensed the script to the Famous Players Film Company, who made it into a motion picture starring John Mason and Hazel Dawn. See The Fatal Card, THE INTERNET MOVIE DATABASE, http://www.imdb.com/title/tt0005305/ (last visited Mar. 4, 2010).

197. There is no indication in any of the reported opinions that Ferris actually published the MacFarlane adaptation, so his copyright may have been defective on that ground as well as on the ground that it infringed Frohman's common law rights. See text accompanying supra note 146. According to the special master, the MacFarlane adaptation changed the original script in many ways, and renamed all of the characters, but retained substantial parts of the original plot and dialogue. Ferris v. Frohman, 131 Ill. App. 307, 307 (1907), rev'd, 87 N.E. 327 (Ill. 1909), aff'd, 223 U.S. 424 (1912). Adapting European scripts for the American stage without permission of the original plays' owners was common throughout the 18th and 19th centuries, see supra notes 128-29 and accompanying text, and nothing in the American copyright statute made it illegal unless the plays had been validly registered in the United States (which became possible in 1891, under the Chace Act, see infra note 213 and accompanying text). Ferris's brief to the U.S. Supreme Court made this argument at some length. See Brief for Petitioner-Appellant in Error at 40-68, Ferris v. Frohman, 223 U.S. 424 (1912) (No. 44). Frohman's brief argued that the common law performing right was subject to no such exceptions, and that the only issue for decision was whether the public 
adaptation toured the Midwest to enthusiastic reviews. ${ }^{198}$ Frohman filed suit in Illinois state court to enjoin Ferris's production on the basis of his common law play right. The trial court referred the case to a special master, who recommended a verdict for the defendant. ${ }^{199}$ The trial court instead found for Frohman, entered an injunction and ordered an accounting of profits. ${ }^{200}$

Ferris appealed, and the court of appeals reversed. ${ }^{201}$ The appellate court reasoned that since British law treated public performance as equivalent to publication, the public performance of the play in London had terminated the authors' common law rights, and left them with only their statutory copyright. The authors, therefore, had no common law rights to sell to Frohman. ${ }^{202}$

Frohman appealed, and the Illinois Supreme Court reversed. ${ }^{203}$ The court held, relying on Drone, that at common law, an author had "an absolute property right in his production which he could not be deprived of so long as it remained unpublished, nor could he be compelled to publish it."204 Statutory copyright, however, remained unavailable to works that had not been printed and published. Since there was no provision for securing copyright for unpublished plays, common law protection remained available and was not waived by public performance. ${ }^{205}$ Ferris appealed to the U.S.

performance of the play in England forfeited its common law copyright protection worldwide. Brief of Respondant-Appellee in Error at 13-37, Ferris v. Frohman, 223 U.S. 424 (1912) (No. 44).

198. See, e.g., Another Big Hit: The "Fatal Card" Proves the Strongest Play Yet Seen at Low Prices, CEDAR RAPIDS RePublican, Aug. 30, 1900, at 1, col. 3.

199. See Ferris, 131 Ill. App. at 308-09.

200. See Ferris, 223 U.S. at 430.

201. Ferris, 131 Ill. App. at 314.

202. Id. at 312-14.

When the authors published the play at the Adelphi Theatre, London, it was with their consent, as the record shows, That act was done and assented to under the law there in force, which expressly provided that it should be the legal equivalent "to the first publication of any book."

....

It follows, we think, that the English authors of this play had no property rights in the United States, which they could confer upon the appellee, Frohman ... at any time subsequent to the publication in London. We are, therefore, of the opinion that appellees, complainants below, failed to establish an exclusive right to produce the play in the United States ....

203. Ferris, 87 N.E. at 332.

204. Id. at 328 (citing DRONE, supra note 1, at 101 et. seq.).

205. Id. (citing DRONE, supra note 1, at 119). The 1909 Act made it possible for the first time to register copyright in an unpublished play. See infra note 215 and accompanying text. The facts of the Frohman case preceded the enactment of the 1909 Act, even though the 
Supreme Court, which, in a unanimous opinion by Justice Hughes, affirmed. ${ }^{206}$

The basis for the Supreme Court's jurisdiction was not straightforward. The Illinois Supreme Court had decided the case entirely as a matter of Illinois state common law, and Frohman objected that the appeal raised no federal question. ${ }^{207}$ Justice Hughes held, however, that the fact that Ferris had registered a copyright in MacFarlane's adaptation provided a federal basis for appellate jurisdiction, because the decision denied Ferris a right otherwise secured by federal copyright law. ${ }^{208}$ Beginning with the observation that " $[1] \mathrm{t}$ is not open to dispute that the authors of 'The Fatal Card' had a common law right of property until it was publicly performed," the Court held that neither the English performance nor the English statute had forfeited that right. "The public representation of a dramatic composition, not printed and published, does not deprive the owner of his common law right, save by operation of statute. At common law, the public performance of the play is not an abandonment of it to the public use."209

The British statutes, the Court continued, did not affect common law rights in the United States, so the authors were free to convey it to Frohman. ${ }^{210}$ That being the case, MacFarlane's adaptation "was simply a piratical composition," and not entitled to federal copyright protection. ${ }^{211}$

As Drone had, the Court began with the premise that authors had unqualified common law rights and asked whether something had happened to take those rights away. ${ }^{212}$ Finding that no statute had done so, the Court skipped right past the question of the appropriate scope of the common law right to the determination that defendants had necessarily invaded it.

Common law play right was a kluge. Courts had invented it to fill gaps in statutory protection, which applied only to printed, published works by United States citizens or residents. Drone expanded it because it represented a nearly blank canvas on which to paint his theories of the appropriate scope

Supreme Court's eventual decision was handed down three years later. Nothing in the language of Justice Hughes' opinion, however, suggests that the unavailability of statutory copyright for unpublished works before 1909 figured in the U.S. Supreme Court's reasoning.

206. Ferris v. Frohman, 223 U.S. 424 (1912).

207. Id. at $430-31$.

208. Id. at 431

209. Id. at $434-35$.

210. Id. at 436-37.

211. Id. at 437. None of the published opinions in the case addressed the similarities between the original script and the MacFarland adaptation, so it is difficult to know whether Ferris's "piratical composition" was more similar to Frohman's than the successful Daly and Boucicault adaptations had been similar to their European antecedents.

212. Id. at 434-37. 
of natural-law based common law literary property. Courts followed Drone both because his treatise seemed comprehensive and because they were drawn, during the period, to the concept of a theoretically coherent body of natural law that expressed itself in the particulars of common law. Congress, however, had already begun to address the gaps that had made common law play right seem necessary.

In 1891, after heavy and long lobbying by playwrights, Congress passed the Chace international copyright bill, extending copyright to foreign nationals so long as they complied with statutory procedures still including registration, publication with notice, and deposit of copies. ${ }^{213}$ In 1897 , Congress passed a law imposing criminal penalties for unauthorized public performance of dramatic or musical compositions. ${ }^{214}$ In 1909, in connection with the general revision of copyright, Congress finally enacted a provision enabling the author or proprietor of a dramatic composition not reproduced for sale to secure federal copyright protection through registration and deposit. ${ }^{215}$ Thus, the United States had finally added to its law the sort of provisions that playwrights argued were necessary to protect their work. For dramatists who preferred it, moreover, there was the potentially boundless and perpetual protection of common law play right a la Eaton Drone. ${ }^{216}$

\section{E. Whose Play Right?}

The reader who has been paying attention will have noticed that very few of the complainants in the cases thus discussed were actual playwrights. ${ }^{217}$ Both common law and statutory claims were pressed on behalf of proprietors who bought all rights from authors, typically for a flat fee. Except for playwrights who managed their own theatre companies, neither American nor European dramatists controlled the American rights to their plays. ${ }^{218} \mathrm{By}$

213. Act of Mar. 3, 1891, ch. 565, 26 Stat. 1106.

214. Act of Jan. 6, 1897, ch. 4, 29 Stat. 481.

215. Act of Mar. 4, 1909, \11, 35 Stat. 1075, 1078. The 1909 Act also expressly preserved the right of an "author or proprietor of an unpublished work, at common law or in equity, to prevent the copying, publication, or use of such unpublished work without his consent." Id. $\int 2$.

216. See, e.g., O’Neill v. Gen. Film Co., 157 N.Y.S. 1028 (App. Div. 1916).

217. Two of the more litigious claimants, Augustin Daly and Dionysus Bouciault, were in fact playwrights some of the time, but they were also theatre managers. And Daly, although apparently terrifically prolific, appears not to have written many of the plays that he claimed. See generally MARvin Felheim, The Theater of Augustin Daly: AN ACCOUnT of the Late Nineteenth Century American Stage 122-40, 144, 220-22 (1956) (identifying some of Daly's unattributed collaborators).

218. See, e.g., WALSH, supra note 129, at 32-34 and sources there cited. 
the early 20th century, the law may have become playwright-friendly, but customary theatre practice had not.

By the end of the 19th century, theatre managers had discovered that rather than maintaining a stock company to present a season of plays in repertory at a single theatre, it was more profitable to open a show in New York City with a bankable star, run it until audience attention flagged, and then tour it to cities throughout the country. ${ }^{219}$ The principal actors and the scenery would need to be transported from city to city, but the managers of local houses could provide extra actors and crew. ${ }^{220}$ Under this model, the economics of an efficient touring route became more important than the script, which was often merely a vehicle for the bankable star of the day. Theatrical producers focused on leasing or purchasing theatres in cities to facilitate lucrative tours. Charles Frohman allied himself with producers Abe Erlanger, Marc Klaw, Al Hayman, Samuel Nixon, and Fred Zimmerman to pool their theatres into a national chain and book tours through a central office. ${ }^{221}$ Within a short time, the syndicate had an effective monopoly over American play houses, and began to demand concessions from actors, copyright owners, rival managers, and booking agents. ${ }^{222}$ Unhappy managers formed a splinter association of producers headed by the Shubert brothers to do battle with the trust. ${ }^{223}$ Both groups competed by acquiring and building new playhouses, investing in vaudeville and novelty attractions, and seeking the allegiance of each others' members. ${ }^{224}$ By the time of the first World War, there were a glut of theatres, and too few attractions to fill them. ${ }^{225}$

Empty playhouses and demand for more economical entertainment helped motion pictures eclipse live theatre more quickly than anyone would have believed possible. ${ }^{226}$ Movies had two huge advantages over stage

219. See BERNHEIM, supra note 123, at 28-31; OwEN DAVIS, My FIRST FIFTY YeARS IN THE THEATRE 27-41 (1950); HenNEKE, supra note 129, at 84-96, 175-92; JERry STAGG, THE BROTHERS SHUBERT 14-16 (1968).

220. See BERNHEIM, supra note 123, at 28-29, 34-37.

221. See id. at 40-50; WALSH, supra note 129, at 19-31.

222. See Bernheim, supra note 123, at 44-63; Glenn Hughes, A History of AMERICAN TheATre 1700-1950, at 317-18 (1951); GeORge Middleton, These Things Are Mine: The Autobiography of A Journeyman Playwright 53-55 (1947); STAGg, supra note 219, at 16-17, 29-51; Sean P. Holmes, All The World's a Stage! The Actors' Strike of 1919, 91 J. OF AM. HIST. 1291, 1292-95 (2005); Steve Travis, The Rise and Fall of the Theatrical Syndicate, 10 EDUC. THEATRE J. 35 (1958).

223. See BERNHEIM, supra note 123, at 64-67.

224. See id. at 67-74.

225. See id. at 75-84.

226. See id. at 85-92; HugHes, supra note 222, at 319; MidDlETON, supra note 222, at $374-76$. 
productions: they appealed to broader audiences and their tickets were much cheaper. ${ }^{227}$ By the 1920s, the motion picture industry had triumphed, and, at least outside of New York City, theatre was already in decline. ${ }^{228}$

The war between the syndicate and the independent producers, meanwhile, had not been kind to working conditions for actors or playwrights. ${ }^{229}$ The commercial producers' focus on theatre buildings and famous stars had led to steady erosion in the perceived importance of ordinary actors and dramatists, and their bargaining power as individuals was modest. ${ }^{230}$ In 1919, New York City actors formed a union, and, in August they went on strike, paralyzing Broadway theaters for a month. ${ }^{231}$ When performances resumed, the Actors Equity Association had managed to negotiate a minimum contract for its members. In response, playwrights formed a labor union of their own, and started talking about persuading producers to accept a minimum dramatists' contract. ${ }^{232}$ They compared the different contracts that they had signed, and found wide variation. Some playwrights wrote scripts as works made for hire, or were required to invest their own money in productions of their plays. ${ }^{233}$ The Charles Frohman Company insisted on the playwright's ceding at least half of the stock performance and motion picture rights and performance rights in any music. ${ }^{234}$ Many producers felt no compunction about rewriting lines or miscasting roles. Yet efforts to persuade playwrights to band together to insist on better pay or more artistic control had so far failed. ${ }^{235}$

What brought matters to a head was the question of what we now refer to as subsidiary rights. Producers insisted on controlling licensing of the plays they purchased and sharing any earnings after its initial production. ${ }^{236}$ They

227. BERNHEIM, supra note 123 , at 88.

228. See id. at 85-92; Barnard HewitT, TheAtre U.S.A. 383 (1959); MidDleton, supra note 222 , at 376-77.

229. See MidDLETON, supra note 222, at 45, 53, 60, 68-70, 138-39 (describing problems for playwrights); WALSH, supra note 129, at 32-34 (describing problems for playwrights); Holmes, supra note 222, at 1293-95 (describing poor working conditions for actors).

230. See BERNHEIM, supra note 123, at 67-79. Both the Syndicate and the Shubert allies had invested heavily in vaudeville to fill their theatres, see $i d$. at 67-69, further diminishing the importance of dramatic actors and scripts.

231. See HuGHES, supra note 222, at 377; Holmes, supra note 222, at 1299-1315.

232. See Thomas James Walsh, Playwrights and Power: The Dramatists' Guild Struggle for the 1926 Minimum Basic Agreement, in ART, GlitTer And Glitz: Mainstream Playwrights AND Popular Theatre in 1920s America 107, 108-113 (Arthur Gewirtz \& James J. Kolb eds., 2004).

233. See id.; MidDLETON, supra note 222, at 311-13.

234. See Walsh, supra note 232 at 108-09.

235. See MidDLETON, supra note 222, at 304-09.

236. See Walsh, supra note 232, at 107-09. 
were particularly eager to sell their scripts to the new movie industry. The Fox Film Corporation approached several major producers, offering to pay the producers a salary in return for giving Fox both a say in the plays they produced and an option to purchase the movie rights. ${ }^{237}$ Playwrights argued that if they did not gain control of their copyrights, the only plays any theater would be willing to produce would be the plays that seemed suitable for film. ${ }^{238}$ They devised a minimum basic agreement under which the dramatist would keep the copyright to the play and creative control of the production; the producer would agree to pay a royalty in the form of a percentage of the gross box office receipts from the production; and the author would receive not less than half of the proceeds from a motion picture sale. The dramatists agreed with one another that they would refuse to give permission to stage any of their scripts to a producer who did not agree that henceforth, he would use the minimum contract for all American dramatists and all New York productions. ${ }^{239}$ Producers objected to the playwrights' insistence on copyright ownership and creative control. ${ }^{240}$ After a significant amount of blustering, and some preliminary skirmishing in court, $^{241}$ though, the producers agreed. ${ }^{242}$

Why did the producers go along? Both the idea that theatrical entertainment was exempt from the antitrust laws and the claim that the Dramatists Guild should be treated as a labor union were more colorable in the 1920 s than they are today. ${ }^{243}$ The majority of established playwrights insisted they would refuse to sign any production contract with a manager

237. See id. at 108-10.

238. See MidDleton, supra note 222, at 308. Other developments had exacerbated the problem. In 1910, Dam v. Kirk La Shelle Co., 175 F. 902 (2d Cir. 1910), had held that the initial assignee of a copyright was the sole copyright owner, and that an author could not, consistently with the statute, assign some exclusive rights but retain others. Under this ruling, copyrights were not divisible and the first producer of a play claimed not only the public performance rights, but the book publishing and motion picture rights as well. See Copyrights: Hearings on H.R. 11258 Before the H. Comm. on Patents, 68th Cong. 45, 48 (1925) (statement of Ellis Parker Butler, Authors' League of America).

239. See MidDLETON, supra note 222, at 298-331.

240. See WALSH, supra note 129, at 114-19.

241. See Shuberts Seek. Stay on Authors' Guild: Producers to Carry Fight on "Tyrannical" Practices to Supreme Court Monday, N.Y. TimeS, Apr. 23, 1927, at 15; Shuberts Start War on Dramatists: Ask Injunction Against Guild Charging Secondary Boycott, N.Y. TimeS, Apr. 22, 1927, at 9.

242. See MidDleton, supra note 222, at 322-32; STAGG, supra note 219, at 250.

243. See Hart v. B. F. Keith Vaudeville Exch., 12 F.2d 341, 344 (2d Cir. 1926) (dismissing antitrust suit against agent for vaudeville performers because "the business of acting in a theater is purely a state affair"); People v. Klaw, 106 N.Y.S. 341, 354 (Crim. Ct. 1907) (dismissing antitrust indictment because "I have failed to find any decision, nor has my attention been directed to any decision, classifying theatrical amusements as articles of 'trade' and 'commerce." ") 
who had not agreed to be bound by the Guild's minimum basic agreement ("MBA"). ${ }^{244}$ The actors' strike had demonstrated that collective action could close theatres. The new infusion of money from movie studios was significant, playwrights would be necessary parties to the sale of new scripts to the film companies, and producers may have believed them when they threatened to withhold their work. Perhaps, even then, it was clear that the money involved in movies would eventually dwarf the money to be made from live theatre, and devising a way to share the proceeds from the sale of film rights seemed important enough to make compromises on issues of creative control and copyright ownership worthwhile. Or, it may be that playwright/producer relations were always friendlier and less antagonistic than actor/producer relations. A playwright could, after all, take the next play elsewhere. $^{245}$ In any event, by the fall of 1927, all major commercial producers had agreed with the dramatists' terms.

Ironically, the 1926-27 season represented the historical peak for new play production on Broadway, with 188 new plays. ${ }^{246}$ Broadway productions of new plays have declined steadily since; in 2007-08, only seven new plays opened on Broadway. ${ }^{247}$

The MBA was renegotiated in 1931, 1936, 1941, 1946, 1955, 1961, and $1985,{ }^{248}$ but the essential terms remained the same. Playwrights keep ownership of their copyrights and creative control of stage productions of their scripts. ${ }^{249}$ Producers pay playwrights a minimum percentage of box office receipts. ${ }^{250}$ Producers and playwrights share subsequent earnings and

244. William Klein II, Authors and Creators: Up By Their Own Bootstraps, 14 COMM. \& L. 41, 61-62 (1992).

245. The fledgling Guild was careful to recruit the most lucrative playwrights from each producer's stable. See MIDDLETON, supra note 222, at 316.

246. Todd London, Ben Pesner \& Zannie Giraud Voss, Outrageous Fortune: The Life AND Times of THE New AMERICAN Play 23-34 (2009).

247. Id. at 24 .

248. See WALSH, supra note 129, at 134-38 (comparing 1931 and 1936 contracts with 1926 contract); $i d$. at 160-63 (explaining 1955 contracts); Alvin Deutsch, MBPC: Resquesciat in Pace - APC: Quo Vadis, 3 ENT. \& SPORTS LAW. 3 (Spring 1985) (comparing 1985 APC with 1961 MBPC); Klein, supra note 244, at 41, 61-62 (1992) (comparing 1954 MBA with earlier contracts); Michael G. Yamin, Legal Problems in Broadway Theatrical Productions, 21 Bus. L. 453 (1966) (explaining $1961 \mathrm{MBPC})$. The Guild has more recently also promulgated contracts for smaller, nonprofit, and regional theatres. See WALSH, supra note 129, at 190-209; Klein, supra note 244, at 64-65; Mervyn Rothstein, Dramatists Guild Writes a Contract for its Members, N.Y. Times, Aug. 30, 1989, at C19.

249. See, e.g., Approved Production Contract for Plays $\iiint_{1.06}$, 8.01, reprinted in FARBER, supra note 8 , at $177,179,201-02$.

250. See id. SS 4.01-4.04, at 184-91. 
split the receipts from sales of film rights. ${ }^{251}$ There has been controversy, and litigation. Producers filed antitrust suits claiming that the Dramatists Guild violates the antitrust laws. ${ }^{252}$ In 1945, the Court of Appeals for the Second Circuit agreed, ${ }^{253}$ but ended up dismissing the case on the ground that the plaintiff had shown no damage. ${ }^{254}$ In 1982, producers sued again on similar claims. ${ }^{255}$ The Guild filed a counterclaim asserting that the producers had themselves violated the antitrust laws by conspiring to fix playwright compensation at an artificially low level. ${ }^{256}$ The litigation settled before anything too final could happen. ${ }^{257}$ When a new round of contract

251. See id. os 11.01-11.08, at 216-26.

252. See, e.g., Drama Guild Sued to End 'Monopoly, 'N.Y. Times, Mar. 12, 1941, at 23.

253. Ring v. Spina, 148 F. 2d 647 (2d Cir. 1945) (preliminary injunction); see also Ring v. Author's League of Am., 186 F.2d 637 (2d Cir. 1951) (appeal after jury verdict).

254. Author's League of Am., 186 F.2d 637. After the Second Circuit ruled that plaintiff independent producer had made a prima facie showing of an antitrust violation and ordered the trial court to enter a preliminary injunction, Spina, 148 F.2d at 651-54, the trial court submitted the question whether the Guild was a labor union (and thus entitled to the labor antitrust exemption) to the jury, which concluded that it was not, and that the Guild had violated the antitrust laws. Author's League, 186 F.2d at 639. Both Ring and the Authors' League appealed. In an apparent attempt to limit the damage of ruling the Guild to be illegal, Judge Learned Hand declined to revisit the antitrust issue:

$[\mathrm{T}]$ he League is naturally concerned that it shall not be held to be a conspiracy in violation of the Anti-Trust Acts. It vigorously protests its innocence and its beneficence; it is conscious of no wrongdoing, and asserts that its existence is essential to the protection of authors and composers. Such purposes would of course not protect it, if it is in fact a combination in restraint of trade or an attempted monopoly; but they are relevant in deciding whether we should decide issues in which the plaintiff has only the most shadowy interests. We hold therefore that the judgment should not have decided that, if the authors revive the play they must give the plaintiff an opportunity to "produce" it on an equal footing with anyone else, and that it should have contained no injunction. However, we hasten to add that we leave open all legal questions which such issues involve; we wish to make it entirely clear that we are not be be understood either to throw any doubt upon, or to affirm, what we said when we granted the temporary injunction; we merely decide that the necessity for such affirmance does not arise.

Id. at 643 .

255. Barr v. Dramatists Guild, Inc., 573 F. Supp. 555 (S.D.N.Y. 1983); see Carol Lawson, Dramatists Guild Sued Over Royalty Payments, N.Y. TIMES, July 28, 1982, at C19, col. 1.

256. Barr, 573 F. Supp. at 558-59.

257. Leslie Bennett, Writers and Producers Reach Contract Accord, N.Y. TIMES, Feb. 27, 1985, at C21; see WALSH, supra note 129, at 176-89 (describing negotiations that resulted in the settlement of the litigation). The Guild and League of American Theatres and Producers agreed to characterize the 1985 Approved Production Contracts as recommended rather than mandatory, but the Guild continues its policy of disciplining members who sign a contract that does not substantially comply with the Guild's approved minimum terms. 


\section{BERKELEY TECHNOLOGY LAW JOURNAL］[Vol. 25:1381}

negotiations raised the specter of a new antitrust suit in 2002, famous playwrights persuaded Senators Hatch and Schumer to introduce the Playwrights Licensing Relief Act. ${ }^{258}$ The bill would have exempted playwrights from antitrust liability for participating in discussions or negotiations to facilitate a standard form contract with producers. ${ }^{259}$ Senators Hatch and Kennedy and Representative Coble reintroduced the bill in the following Congress, where it received a hearing, but no further action. ${ }^{260}$

The enactment of the 1976 Copyright Act has, in theory, completely obliterated any copyright distinction between published and unpublished plays. To the extent a common law performance right existed at some time under the 1870 or 1909 Acts, the 1976 Act makes the right a thing of the past. The elimination of publication or registration as a condition of statutory copyright also enabled other creative contributors to claim copyright in their

Members who are expelled from the Guild or who resign to avoid being expelled from the Guild may rejoin after a year.

258. S. 2082, 107th Cong. (2002); see Jesse McKinley, Legislation to Help Playwrights Negotiate, N.Y. Times, Apr. 12, 2002, at E6, col. 1.

259. Section 2 of the Bill would have provided:

(a) IN GENERAL- Subject to subsection (c), the antitrust laws shall not apply to any joint discussion, consideration, review, action, or agreement for the express purpose of, and limited to, the development of a standard form contract containing minimum terms of artistic protection and levels of compensation for playwrights by means of-

(1) meetings, discussions, and negotiations between or among playwrights or their representatives and producers or their representatives; or

(2) joint or collective voluntary actions for the limited purposes of developing a standard form contract by playwrights or their representatives.

(b) ADOPTION AND IMPLEMENTATION- Subject to subsection (c), the antitrust laws shall not apply to any joint discussion, consideration, review, or action for the express purpose of, and limited to, reaching a collective agreement among playwrights adopting a standard form contract developed pursuant to subsection (a) as the participating playwrights sole and exclusive means by which participating playwrights shall license their plays to producers.

(c) AMENDMENT OF CONTRACT- A standard form of contract developed and implemented under subsections (a) and (b) shall be subject to amendment by individual playwrights and producers consistent with the terms of the standard form contract.

S. 2082, § 2 .

260. See generally The Playwrights Licensing Antitrust Initiative Act: Safeguarding the Future of American Live Theater: Hearing on S. 2349 Before the S. Judiciary Comm., 108th Cong. (2004). Representative Coble reintroduced the Bill in the 109th Congress. See H.R. 532, 109th Cong. (2005). It died there. 
authorship as part of any production that is fixed in tangible form. ${ }^{261}$ Directors and other collaborators have asserted copyright ownership of their contributions, ${ }^{262}$ to be met with protests from the Guild. ${ }^{263}$ The Dramatists Guild insists that recognizing any other contributor as an author would mean the death of drama as we know it. ${ }^{264}$ Although some of these disputes led to litigation, most of the lawsuits have also settled. ${ }^{265}$

261. See 17 U.S.C. $\iint 102(a), 103$ (2006). Some commentators have argued that a derivative author owns no copyright in a licensed derivative work unless the owner of the copyright in the underlying work has authorized it. See, e.g., William Patry, Copyright in Stage Directions?, PATRY COPYRIGHT Blog, (Jan. 29, 2006, 8:42 AM), http://williampatry.blogspot.com/2006/01/copyright-in-stage-directions.html ("If, as Einhorn apparently represented to the Copyright Office, his work is a derivative work of the play script, under Section 103, he is unlikely to be able to have a valid copyright without the playwright's permission, which presumably here would be denied.”). This is careless reading. So long as the derivative work is created lawfully, sections 102 and 103 provide for automatic copyright protection, regardless of the copyright owner's permission. See also H.R. REP. No. 99-1476, at 58 (1976) ("Under this provision, copyright could be obtained as long as the use of the preexisting work was not 'unlawful,' even though the consent of the copyright owner had not been obtained."). Were this not the case, there would be no need to provide expressly in section 115(a)(2) that when a sound recording is made pursuant to a statutory compulsory license (as distinguished from a negotiated license or a Harry Fox license), the new musical arrangement authorized by the statute will not be protected by copyright unless the owner of the copyright in the underlying musical composition consents.

262. Jesse Green, Exit, Pursued by A Lanyer, N.Y. Times, Jan. 29, 2006, at Section 2: Arts \& Leisure 1, col. 5; see, e.g., Mullen v. Soc'y of Dirs. \& Choreographers, No. 06 C 6818, 2007 U.S. Dist. LEXIS 75235 (N.D. Ill. Sept. 28, 2007) (suit over copyright in direction, choreography and scenic design of Urinetown); Einhorn v. Mergatroyd Prods., 426 F. Supp. 2d 189 (S.D.N.Y. 2006) (suit over copyright in Edward Einhorn's direction of Tam Lin); Mantello v. Hall, 947 F. Supp. 92 (S.D.N.Y. 1996) (suit over copyright in Joe Mantello's direction of Love!'Valour!Compassion!).

263. See Dramatists Guild of Am., Statement: Dramatist Copyright and Intellectual Property Rights, http://dramatistsguild.com/about_statements_copyright.aspx (last visited Apr. 2, 2010):

The Council of the Guild has become aware that directors, dramaturgs and other theatrical collaborators have from time to time claimed copyright and other ownership interests in any such changes or contributions for which they claim to be responsible. They have attempted to establish their claims, among other means, by videotaping performances or filing with the Copyright Office the dramatist's script with changes, notations and other additions claimed by these collaborators. Such claims and actions infringe on the rights of dramatists to own and control their plays, and may inhibit the opportunities of other professionals, and audiences, to participate in the re-creation and enjoyment of the play.

Id.

264. E.g., Weidman, supra note 10. The Guild argues that its members' contracts require the playwright's approval of any changes to the script, and oblige the producer to assign ownership of any changes to the playwright. Since the production is licensed subject to that 
Today, playwrights in America retain both copyright ownership and creative control in their plays. Those strong copyright rights have not, however, made playwriting remunerative. A 2009 study by the Theatre Development Fund concluded that it is no longer possible for even the most successful playwrights to earn a living from productions of their plays. ${ }^{266}$ Working playwrights need to supplement their incomes with teaching or with writing scripts for film or television under work made for hire contracts.

Meanwhile, the Drone-ish form of common law copyright has entirely died out, forgotten by everyone but the record labels who claim it for their pre-1972 recordings. ${ }^{267}$

\section{CONCLUSION}

What lessons can we draw from the history of common law play right in America? Several lessons seem evident. Most obviously, for all of the authorcentric rhetoric pervading the cases and secondary literature, common law play right was never a playwright's right-it was asserted almost exclusively by and on behalf of the theatre managers and publishers who claimed to be the playwright's assigns. We can miss important information when we take author's rights language at face value, without asking ourselves who is speaking the language and what, exactly, he or she seeks to accomplish.

Second, for legal scholars, a particularly interesting subplot in this story represents what Ann Bartow has termed "the Hegemony of the Copyright Treatise." ${ }^{268}$ Eaton Drone was able to write a thick, comprehensive treatise

clause, the producer has no right to enter into contracts with directors or designers that permit them to retain copyright in their contributions. The Stage Directors and Choreographers Society, which represents directors, has negotiated collective bargaining agreements with Broadway, Off-Broadway, regional, and stock theatres under which both directors and choreographers retain copyright in their contributions. See Stage Dirs. \& Choreographers Soc'y, SDC Contracts: Collectively Bargained Agreements, http://sdcweb.org/index.php?option=com_content\&task=view\&id=40\&Itemid=96 (last visited Apr. 2, 2010).

265. See, e.g., Andrew Gans, Akron Urinetwon Lawsuit Settled, PlayBILl.Com, July 2, 2008, http:/ /www.playbill.com/news/article/119148-Akron-Urinetown-Lawsuit-Settled; Campbell Robertson, A Urinetown Suit is Settled, N.Y. TIMES, Dec. 1, 2007, at B8; Lisa Jo Sagolla, Dance/Movement: Should Stage Direction Be Copyrightable?, BACKSTAGE, May 20, 2008, http://www.backstage.com/bso/esearch/article_display.jsp?vnu_content_id=1003805591.

266. LONDON, PESNER \& VOSS, supra note 246, at 47-96.

267. See Capitol Records v. Naxos of Am., Inc., 372 F.3d 471 (2d Cir. 2004) (certifying common law copyright question to N.Y. Court of Appeals); Capitol Records, Inc. v. Naxos of Am., Inc., 4 N.Y.2d 540 (2005) (holding that N.Y. common law copyright protects sound recordings made before 1972 even if they are in the public domain in their country of origin).

268. Ann Bartow, The Hegemony of the Copyright Treatise, 71 U. CIN. L. REV. 1 (2004). 
because, instead of deriving legal principles from statutes and judicial decisions, he created his legal principles out of whole cloth and discussed judicial decisions to demonstrate where they were consistent and inconsistent with the principles he announced. That allowed Drone to have answers for many questions courts had not addressed, and to pick the winners when court decisions demonstrated a conflict of authority. Drone didn't hide his method, or pretend that he was merely describing the law, rather than seeking to reshape it. Courts and other writers nonetheless relied on Drone as a dependable account of what the law was, rather than an argument about what Drone believed the law ought to become. ${ }^{269}$

Third, the fact that common law performance rights in both England and America did not precede statutory performance rights but followed them, growing up in response to perceived gaps in the rights under the statute, parallels the history of common law printing rights. This history should probably count as another nail in the coffin of the story of copyright's natural right origins in the days of primordial ooze. Further, the histories of the two different flavors of common law copyright suggest that what rights that we perceive as inherent or natural are fundamentally contingent on what rights already have names and a path to enforcement.

Finally, the story reminds us that, for most people, the customs that grow up around what people believe the law to be matter more than what the law really is. Dramatists were able to get exceptional authors' rights through collective action that was not tied to any statute or judicial decision, and they have retained those rights despite (and maybe even in defiance of) later statutes or judicial decisions. Of the 20,000 dramatists who registered the title of their plays without depositing copies and thought they had thereby perfected a federal copyright, most of them got an apparent copyright that

269. The most disturbing example, in my view, is probably William S. Strauss's uncritical parroting of Drone in the 1957 copyright office study on protection for unpublished works. See Strauss, supra note 19. Because the series of studies was in general so meticulous, scholars who came after believed Strauss's description was apt. Strauss may have had a reform agenda. In a law review article published at around the same time, he argued that U.S. common law in general, and common law copyright in particular, provided protection of authors' rights that was substantially equivalent with the droit morale required under article 6bis of the Berne Convention. See William S. Strauss, The Moral Right of the Author, 4 AM. J. COMP. L. 506, 538 (1955). That article, with some additions, became the Copyright Office's 1959 study on moral rights. See William S. Strauss, Study No. 4: The Moral Right of THE Author, reprinted in S. COMM. ON THE JudiCIARY, 86TH CONG., COPYRight LAW Revision: Studies Prepared for the Subcomm. on Patents, Trademarks and Copyrights of the S. COMM. ON THE Judiciary (Comm. Print 1960); Library of CONG., SiXTieth ANNUAL Report of THE REgister of COPYRIGHTS FOR THE FisCAL YEAR ENDING JUNE 30, 1957, at 9-10 (1957). 
probably worked as well for them as the real thing would have. Today, the strong attribution and integrity rights that playwrights claim, and their insistence on denying that their collaborators author contributions, have everything to do with customs and contracts, and very little to do to with copyright law. 